\title{
33. ANALYSIS OF ORGANIC MATTER FROM LEG 81 (ROCKALL PLATEAU)1
}

\author{
A. J. Kaltenback and G. K. Guennel, Marathon Oil Company \\ W. B. Lyons, University of New Hampshire, Durham \\ and \\ A. Moore and J. W. Patton, Marathon Oil Company²
}

\begin{abstract}
Organic geochemical and visual kerogen analyses were carried out on approximately 50 samples from Leg 81 (Rockall Plateau, North Atlantic). The sediments are from four sites (Sites 552-555), Pleistocene to Paleocene in age, and represent significantly different depositional environments and sources of organic matter.

The Pleistocene glacial-interglacial cycles show differences in sedimentary organic matter based on Rock-Eval pyrolysis, organic phosphorus, and pyrolysis/mass-spectrometry analyses. Glacial samples contain more organic carbon, with a larger proportion of reworked organic matter. This probably reflects increased erosion of continental and shelf areas as a result of low sea level stands. Interglacial samples contain a larger proportion of marine organic matter as determined by organic phosphorus and pyrolysis analyses. This immature, highly oxidized marine organic matter may be associated with the skeletal organic matrix of calcareous organisms. In addition, Rock-Eval data indicate no significant inorganic-carbonate contribution to the $S_{3}$ pyrolysis peak.

The Pliocene-Miocene sediments consist of pelagic, biogenic carbonates. The organic matter is similar to that of the Pleistocene interglacial periods; a mixture of oxidized marine organic matter and reworked, terrestrial detritus.

The Paleocene-Oligocene organic matter reflects variations in source and depositional factors associated with the isolation of Rockall from Greenland. Paleocene sediments contain primarily terrestrial organic matter with evidence of in situ thermal stress resulting from interbedded lava flows. Late Paleocene and early Eocene organic matter suggests a highly oxidized marine environment, with major periods of deposition of terrestrially derived organic matter. These fluctuations in organic-matter type are probably the result of episodic shallowing and deepening of Rockall Basins. The final stage of Eocene/Oligocene sedimentation records the accelerating subsidence of Rockall and its isolation from terrestrial sources (Rockall and Greenland). This is shown by the increasingly marine character of the organic matter.

The petroleum potential of sediments containing more than $0.5 \%$ organic carbon is poor because of their thermal immaturity and their highly oxidized and terrestrial organic-matter composition.
\end{abstract}

\section{INTRODUCTION}

The organic matter $(\mathrm{OM})$ in approximately 50 samples from the North Atlantic (Leg 81, Rockall Banks) was studied using several geochemical techniques in conjunction with visual kerogen analysis. The samples are from four sites (Sites 552-555) and are Pleistocene to $\mathrm{Pa}$ leocene age.

The Plio-Pleistocene hydraulic piston core samples (Hole 552A) are believed to represent a complete record of high latitude glacial-interglacial cycles for the North Atlantic (Zimmerman et al., this volume). The very low organic carbon $(\mathrm{OC})$ content of these samples $(0.06-$ $0.20 \%$ ) creates analytical problems but also provides an opportunity to learn more about highly oxidized, deepocean sediments, often encountered in Deep Sea Drilling Project (DSDP) drilling. The purpose of this part of our research was to see if there were discernible differences in OM preserved in glacial versus interglacial sediments.

Another goal of this work was to examine $\mathrm{OM}$ in the Miocene-Paleocene sediments to contribute to under-

\footnotetext{
${ }^{1}$ Roberts, D. G., Schnitker, D., et al., Init. Repts. DSDP, 81: Washington (U.S. Govt. Printing Office).

2 Addresses: (Kaltenback, Guennel, Moore, and Patton) Marathon Oil Company, Denver Research Center, Littleton, CO 80160; (Lyons) Department of Earth Sciences, University of New Hampshire, Durham, NH 03824.
}

standing of the various processes (sedimentologic, paleoceanographic, and tectonic) involved in their formation. Our approach is similar to that of others (Demaison and Moore, 1980; Tissot et al., 1980; Simoneit, 1980; Peters and Simoneit, 1982), who relate sedimentary OM to biogenic source, depositional environment, and diagenetic history.

\section{ANALYTICAL METHODS}

Carbon analyses were performed on the glacial-interglacial samples (Cores 552A-2 and 552A-8) by Brown and Ruth Labs, Houston, Texas. Organic carbon, percentage $\mathrm{CaCO}_{3}$, and organic nitrogen for other samples were determined by conventional DSDP methods on shipboard. The phosphorus analyses were supplied by Dr. W. B. Lyons, University of New Hampshire, Department of Earth Sciences. All other analyses were performed at Marathon Oil Company's Denver Research Center.

\section{Visual Kerogen}

Slides of organic residues from macerated samples were examined with transmitted light at magnifications of 300 and $500 \times$. Table 1 summarizes the visual kerogen results. These include thermal maturation (TAI) based on spore coloration and approximate maceral abundances.

\section{Isotopic Analysis}

Stable isotope compositions for kerogen-carbon, carbonate-carbon, and carbonate-oxygen from glacial-interglacial samples were determined with a Nuclide RMS $6^{\prime \prime}-60^{\circ}$ isotope ratio mass spectrometer. Instrument internal variation does not exceed \pm 0.05 per mil and sample reproducibility is within \pm 0.5 per mil. Results are given in Tables 2 and 3 as $\delta^{13} \mathrm{C}$ and $\delta^{18} \mathrm{O}$ in parts per thousand (per mil) deviation from the PDB Standard. 


\section{A. J. KALTENBACK ET AL.}

Table 1. Visual kerogen assessment of selected samples from Leg 81 (Sites 552, 553, 554, and 555) including approximate maceral abundances and thermal maturation (TAIDRC) based on spore coloration.

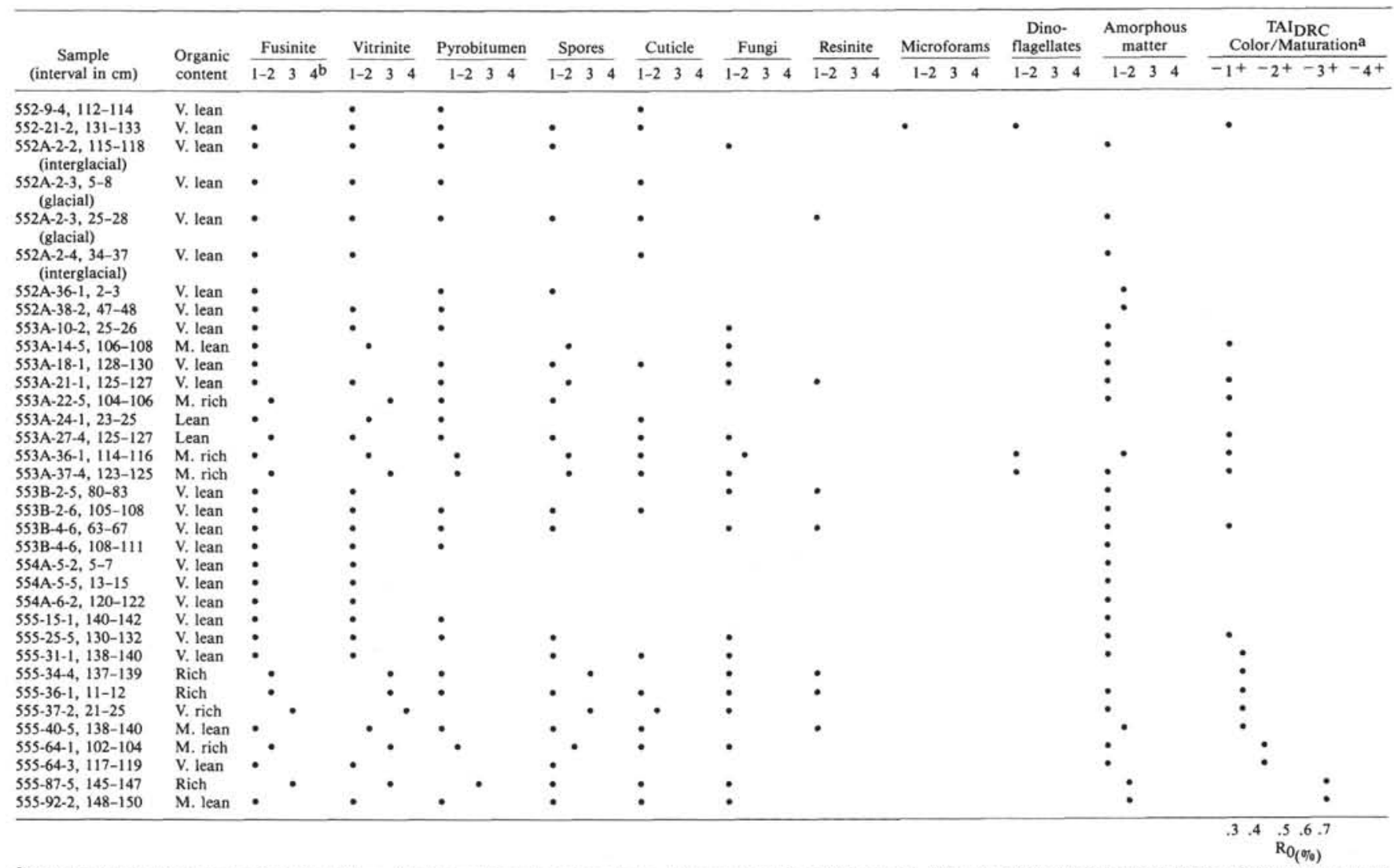

${ }^{a}$ Color/maturation thermal alteration index (TAIDRC) the Denver Research Center scale is $1-10$ versus conventional TAI scale of $1-5$ (Staplin, 1969). This evaluation is based on indigenous spore and

cuticle material. Approximate equivalent vitrinite reflectance $\left(R_{0}\right)$ values are shown versus the TAIDRC.
Maceral abundances are approximate only: $4=$ abundant, $3=$ common, $1-2=$ trace/minor.

Table 2. Geochemical data for Pleistocene glacial-interglacial samples from Leg 81, Cores 552A-2 and 552A-8 and 553B-2 and 553B-4.

\begin{tabular}{|c|c|c|c|c|c|c|c|c|c|c|c|c|c|c|}
\hline $\begin{array}{l}\text { Sub-bottom } \\
\text { depth (m) }\end{array}$ & $\begin{array}{c}\text { Sample } \\
\text { (interval in cm) }\end{array}$ & $\underset{\text { (wt. } \% \text { ) }}{O C}$ & $\begin{array}{c}\text { Carbonate } \\
\text { (wt. } \% \text { as } \mathrm{CaCO}_{3} \text { ) }\end{array}$ & $\begin{array}{l}\mathrm{CO}_{3}(\mathrm{C}) \\
\mathrm{Org}(\mathrm{C})\end{array}$ & $\begin{array}{l}\delta^{13} \mathrm{C}\left(\$_{0}\right) \\
\text { Organic C }\end{array}$ & $\begin{array}{c}\delta^{13} \mathrm{C}\left(7_{0}\right) \\
\text { Carbonate } \mathrm{C}\end{array}$ & $\begin{array}{c}\delta^{18} \mathrm{O}\left(\%_{0}\right) \\
\text { Carbonate } \mathrm{O}\end{array}$ & $\begin{array}{c}\text { Total P } \\
\text { ignited } \\
(\mu M / \mathrm{g} \text { sed.) }\end{array}$ & $\begin{array}{l}\text { Inorganic P } \\
(\mu M / \mathrm{g} \text { sed. })\end{array}$ & $\begin{array}{c}\text { Organic P } \\
(\mu M / g \text { sed. })\end{array}$ & $\begin{array}{r}\text { Mole } \\
\text { (org: } \\
\text { (C/P) }\end{array}$ & $\begin{array}{l}\text { ratio } \\
\text { anic) } \\
(\mathrm{C} / \mathrm{N})\end{array}$ & $\begin{array}{c}S_{3} \\
\text { (mg CO} 2 / 8 \text { sed.) }\end{array}$ & $\begin{array}{c}\% \text { RC } \\
\text { (residual } \\
\text { carbon) }\end{array}$ \\
\hline & & & & & & $r^{1.10}$ & 2.45 & & & & & & & \\
\hline 6.7 & $552 \mathrm{~A}-2-2,115-118$ & 0.08 & 86 & 129 & -23.8 & $\mathrm{~L}_{1.16}$ & $\mathrm{~L}_{2.60}$ & 13.4 & 8.7 & 4.7 & 14 & & 0.82 & 66 \\
\hline 6.9 & $552 \mathrm{~A}-2-2,133-137$ & 0.11 & 58 & 63 & & 1.10 & 2.50 & & & & & & 1.05 & 68 \\
\hline 7.1 & $552 A-2-3,5-8$ & 0.14 & 15 & 13 & -24.2 & 1.53 & 2.06 & 10.7 & 10.8 & - & - & & 1.08 & 76 \\
\hline 7.3 & $552 \mathrm{~A}-2-3,25-28$ & 0.20 & 14 & 8 & & 1.26 & 2.02 & 7.4 & $10.2^{\mathrm{a}}$ & - & - & & 1.05 & 83 \\
\hline 7.6 & $552 \mathrm{~A}-2-3,53-57$ & 0.14 & 18 & 15 & & 0.74 & 1.73 & & & & & & 1.40 & 70 \\
\hline 7.9 & $552 \mathrm{~A}-2-3,82-85$ & 0.13 & 33 & 31 & & 0.89 & 3.43 & & & & & & 1.33 & 68 \\
\hline 8.2 & $552 A-2-3,114-117$ & 0.08 & 36 & 54 & & 1.13 & 3.34 & & & & & & 1.16 & 58 \\
\hline 8.4 & $552 \mathrm{~A}-2-3,141-144$ & 0.14 & 35 & 30 & & 1.09 & 3.40 & & & & & & 1.18 & 74 \\
\hline 8.6 & $522 \mathrm{~A}-2-4,14-17$ & 0.09 & 64 & 85 & & 1.86 & 3.36 & & & & & & 0.97 & 69 \\
\hline 8.8 & $552 \mathrm{~A}-2-4,34-37$ & 0.06 & 78 & 156 & & 1.73 & 3.03 & 8.9 & 6.5 & 2.4 & 21 & & 0.71 & 60 \\
\hline 37.0 & $552 \mathrm{~A}-8-2,137-140$ & 0.08 & 77 & 116 & & 0.34 & 2.37 & & & & & & 0.89 & 65 \\
\hline 37.1 & $552 \mathrm{~A}-8-3,3-7$ & 0.12 & 51 & 51 & & -0.35 & 2.50 & 7.2 & 6.8 & 0.4 & $>250$ & & 1.08 & 71 \\
\hline 37.4 & $552 \mathrm{~A}-8-3,22-26$ & 0.16 & 35 & 26 & -24.7 & -0.52 & 2.22 & 6.4 & $8.3^{\mathrm{a}}$ & - & - & & 1.01 & 81 \\
\hline 37.6 & $552 \mathrm{~A}-8-3,41-44$ & 0.08 & 78 & 117 & & -0.57 & 2.27 & & & & & & 0.90 & 69 \\
\hline 37.7 & $552 \mathrm{~A}-8-3,63-67$ & 0.08 & 70 & 105 & & -0.40 & 1.84 & & & & & & 0.80 & 71 \\
\hline 37.8 & $552 \mathrm{~A}-8-3,73-76$ & 0.09 & 54 & 72 & & -0.65 & 2.28 & & & & & & 0.87 & 70 \\
\hline 37.9 & $552 A-8-3,83-86$ & 0.06 & 76 & 152 & -24.8 & -0.50 & 1.80 & 8.2 & 6.0 & 2.2 & 23 & & 0.79 & 55 \\
\hline 8 & $553 \mathrm{~B}-2-5,80-83$ & 0.17 & 84 & 59 & -25.1 & -0.36 & 1.51 & 10.2 & 8.6 & 1.6 & 89 & 9.9 & 0.94 & 81 \\
\hline 9.5 & $553 \mathrm{~B}-2-6,105-108$ & 0.06 & 8 & 16 & -24.8 & 1.20 & 0.30 & 18.3 & 14.0 & 4.3 & 12 & 2.3 & 0.80 & 20 \\
\hline 28 & $553 \mathrm{~B}-4-6,63-67$ & 0.07 & 73 & 125 & -24.8 & -0.28 & 2.58 & 10.9 & 8.2 & 2.7 & 22 & 8.2 & 1.06 & 44 \\
\hline 28.5 & $553 \mathrm{~B}-4-6,108-111$ & 0.12 & 4 & 4 & -24.6 & 0.29 & 1.15 & 11.2 & 10.2 & 1.0 & 100 & 4.7 & 0.76 & 61 \\
\hline
\end{tabular}

a Inorganic P larger than total P; possible explanations are in text.

\section{Pyrolysis Analysis (Rock-Eval)}

Rock-Eval analysis is described by Espitalié et al. (1977) and Clementz et al. (1979). Pyrolysis provides a rapid measure of hydrocarbon generative potential, maturation, and the degree of oxidation of whole-sediment samples. Most samples were analyzed on shipboard using the Rock-Eval I. These analyses are contained in the organic geochemistry sections of the site chapters (this volume). The glacialinterglacial samples were analyzed with the Rock-Eval II (Delsi). The coefficient of variation for replicate samples is less than $\pm 3 \%$ of measured $S_{2}$ (pyrolyzable hydrocarbons) and $S_{3}$ (pyrolyzable $\mathrm{CO}_{2}$ ) values. This is true for samples with significant amounts $(>0.5 \mathrm{mg} / \mathrm{g}$ sediment) of $S_{2}$ and $S_{3}$. Samples containing smaller amounts of $S_{2}$ and $S_{3}$ give greater variability.

In this study we have defined a pyrolysis factor, percentage residual carbon (RC). Rock-Eval pyrolysis carbon (PC) is defined as: $\mathrm{PC}=$ $\left(S_{1}+S_{2}\right) \times 0.84+\left(S_{3} \times 0.27\right)$, where $S_{1}$ and $S_{2}$ are the hydrocarbon peaks and $S_{3}$ is the $\mathrm{CO}_{2}$ peak. The $S_{3}$ peak is $27 \%$ carbon and we as- 
Table 3. Geochemical data for Miocene-Paleocene samples from Leg 81, Sites 552, 553, 554, and 555.

\begin{tabular}{|c|c|c|c|c|c|c|c|c|c|c|c|}
\hline \multirow{2}{*}{$\begin{array}{c}\text { Sub-bottom } \\
\text { depth (m) }\end{array}$} & \multirow[b]{2}{*}{ Sample } & \multirow{2}{*}{$\begin{array}{c}\mathrm{OC} \\
\text { (wt. \%) }\end{array}$} & \multirow{2}{*}{$\begin{array}{c}\text { Carbonate } \\
\text { (wt. } \% \text { as } \mathrm{CaCO}_{3} \text { ) }\end{array}$} & \multirow{2}{*}{$\begin{array}{l}\delta^{13} \mathrm{C}\left(\%_{0}\right) \\
\text { Organic C }\end{array}$} & \multirow{2}{*}{$\begin{array}{c}\text { Total P } \\
\text { ignited } \\
(\mu M / g \text { sed. })\end{array}$} & \multirow{2}{*}{$\begin{array}{l}\text { Inorganic } \mathrm{P} \\
(\mu M / \mathrm{g} \text { sed. })\end{array}$} & \multirow{2}{*}{$\begin{array}{c}\text { Organic P } \\
(\mu M / \mathrm{g} \text { sed. })\end{array}$} & \multicolumn{2}{|c|}{$\begin{array}{l}\text { Mole ratio } \\
\text { (organic) }\end{array}$} & \multirow[b]{2}{*}{ Age } & \multirow{2}{*}{$\begin{array}{l}\text { Lithologic } \\
\text { Unit }\end{array}$} \\
\hline & & & & & & & & $(\mathrm{C} / \mathrm{P})$ & $(\mathrm{C} / \mathrm{N})$ & & \\
\hline 163 & $552-6-3,112-114$ & 0.05 & 83 & -25.0 & 8.2 & 5.5 & 2.7 & 15 & 6 & m. Miocene & $11 \mathrm{a}$ \\
\hline 170 & $552 A-36-1,2-3$ & 0.05 & 90 & -25.2 & - & - & - & - & 6 & m. Miocene & IIb \\
\hline 180 & $552 \mathrm{~A}-38-2,47-48$ & 0.17 & 21 & -25.5 & - & - & - & - & 20 & m. Eocene & IVa \\
\hline 183 & $552-9-4,112-114$ & 0.09 & 24 & -25.9 & 36.7 & 29.2 & 7.5 & 10 & 11 & m. Eocene & IVa \\
\hline 212 & $552-12-5,118-120$ & 0.06 & 8 & -26.8 & 11.0 & 10.0 & 1.0 & 50 & 4 & e. Eocene & $\mathrm{IVb}$ \\
\hline 247 & $552-16-1,10-14$ & 0.17 & 13 & -27.8 & 14.7 & $15.3^{\mathrm{a}}$ & - & - & 10 & e. Eocene & $\mathrm{IVb}$ \\
\hline 292 & $552-21-2,131-133$ & 0.13 & 19 & -28.6 & 11.5 & 10.0 & 1.5 & 72 & 8 & e. Eocene & IVc \\
\hline 240 & $553 \mathrm{~A}-10-2,25-26$ & 0.01 & 71 & -26.9 & 45.7 & 29.3 & 16.4 & & 1 & m. Eocene & IVa \\
\hline 280 & $553 \mathrm{~A}-14-5,106-107$ & 0.76 & 2 & -26.2 & 11.0 & 11.0 & - & - & 30 & e. Eocene & IVc \\
\hline 340 & $553 A-21-1,125-126$ & 0.18 & 1 & -26.7 & 22.7 & 19.2 & 3.5 & 43 & 21 & e. Eocene & IV \\
\hline 360 & $553 \mathrm{~A}-22-5,104-105$ & 1.09 & 0 & -26.6 & 16.1 & 10.8 & 5.3 & 171 & 32 & e. Eocene & IVc \\
\hline 370 & $553 \mathrm{~A}-24-1,23-24$ & 0.37 & 0 & - & - & - & - & - & 22 & e. Eocene & IVc \\
\hline 405 & $533 \mathrm{~A}-27-4,125-127$ & 0.31 & 0 & -25.8 & 18.0 & $20.9^{\mathrm{a}}$ & - & - & 13 & 1. Paleocene & IVd \\
\hline 490 & $553 \mathrm{~A}-36-1,114-116$ & 1.10 & 1 & -26.7 & 31.4 & 29.7 & 1.7 & 539 & 32 & 1. Paleocene & IVf \\
\hline 500 & $553 \mathrm{~A}-37-4,123-125$ & 1.00 & 3 & - & - & - & - & - & 29 & 1. Paleocene & IVf \\
\hline 117 & $554 A-5-2,5-7$ & 0.04 & 81 & - & - & - & - & - & 9 & 1. Miocene & IIIa \\
\hline 122 & $554 \mathrm{~A}-5-5,13-15$ & 0.11 & 9 & -25.1 & 44.5 & 38.3 & 6.2 & 15 & 0 & e. Eocene & IV \\
\hline 126 & $554 \mathrm{~A}-6-2,120-122$ & 0.02 & 62 & - & - & - & - & - & 17 & e. Eocene & IV \\
\hline 168 & $555-15-1,140-141$ & 0.07 & 94 & -26.8 & 12.0 & 9.6 & 2.4 & 24 & 8 & 1. Miocene & $\mathrm{IIa}$ \\
\hline 270 & $555-25-5,130-131$ & 0.08 & 92 & -24.4 & - & - & - & - & 9 & e. Miocene & IIb \\
\hline 320 & $555-31-1,138-139$ & 0.25 & 3 & -28.2 & 18.8 & 18.2 & 0.6 & 347 & 29 & e. Eocene & IIIb \\
\hline 355 & $555-34-4,137-138$ & 1.95 & 1 & -25.8 & 21.6 & 20.5 & 1.1 & 1477 & 57 & e. Eocene & IIIc \\
\hline 366 & $555-36-1,11-12$ & 0.71 & 45 & -24.7 & 43.6 & 39.4 & 4.2 & 141 & 83 & e. Eocene & III c \\
\hline 376 & $555-36, \mathrm{CC}$ & 0.10 & 78 & -25.0 & 74.9 & 62.9 & 12.0 & 7 & 29 & e. Eocene & IIIc \\
\hline 378 & $555-37-2,21-25$ & 4.10 & 2 & -25.0 & 30.4 & 26.3 & 4.1 & 833 & 60 & e. Eocene & IIIc \\
\hline 390 & $555-38-3,13-14$ & 2.30 & 1 & -25.8 & - & - & - & - & 45 & e. Eocene & IIIc \\
\hline 413 & $555-40-5,138-139$ & 0.94 & 0 & -26.4 & 9.5 & 9.5 & - & - & 37 & e. Eocene & IIIc \\
\hline 453 & $555-45-1,145-146$ & 1.03 & 2 & -27.0 & 20.9 & $22.6^{\mathrm{a}}$ & - & - & 30 & e. Eocene & IIIc \\
\hline 521 & $555-52-2,78-79$ & 2.55 & I & -26.6 & - & - & - & - & 43 & 1. Paleocene & IIId \\
\hline 634 & $555-64-1,102-103$ & 0.91 & 0 & -26.4 & - & - & - & - & 35 & 1. Paleocene & IIIe \\
\hline 638 & $555-64-3,117-118$ & 0.10 & 2 & -25.5 & 14.2 & $17.9^{\mathrm{a}}$ & - & - & 12 & 1. Paleocene & IIle \\
\hline 858 & $555-87-5,145-146$ & 2.70 & 2 & -26.9 & 13.1 & 12.6 & 0.5 & 4500 & 53 & 1. Paleocene & IVb \\
\hline 902 & $555-92-2,148-150$ & 0.67 & 2 & -26.8 & 34.8 & 34.8 & - & - & 39 & 1. Paleocene & IVb \\
\hline
\end{tabular}

${ }^{\mathrm{a}}$ Inorganic $\mathrm{P}$ larger than total $\mathrm{P}$, possible explanations are in text.

sume $S_{1}$ and $S_{2}$ are approximately $84 \%$ carbon. PC has the units mg $\mathrm{C} / \mathrm{g}$ sediment and $\mathrm{OC}$ is normally expressed as $\mathrm{g} \mathrm{C} / 100 \mathrm{~g}$ sediment, thus,

$$
\% \mathrm{RC}=\frac{(\mathrm{OC} \times 10)-\mathrm{PC}}{\mathrm{OC} \times 10} \times 100
$$

The IFP Rock-Eval standard, which is an "oil-prone" type-II kerogen, gives $68 \% \mathrm{RC}$ by our analysis. A Marathon Rock-Eval standard (Monterey mudstone), also type II but slightly more oxidized, gives $71 \% \mathrm{RC}$. There is a significant marine contribution to the OM in both of these samples. A recent algal sample, which is type I by Rock-Eval analysis, has less than $30 \%$ RC.

\section{Pyrolysis Mass Spectrometry}

Pyrolysis mass spectrometry (pyrol/MS) was performed as described by Patton and Moore (1982) and Patton et al. (in press). This technique involves the thermolysis $\left(30-750^{\circ} \mathrm{C}\right.$, at $20^{\circ} \mathrm{C} / \mathrm{min}$.) of wholesediment samples in the source of a Varian $\mathrm{CH}-5$ mass spectrometer and is similar to that reported by Souron et al. (1974). The hydrocarbon fragments released by pyrolysis are studied to characterize the sedimentary OM. The orthographic plots (Fig. 1, for selected samples) of $Z$ values versus pyrolysis temperature are a convenient way of visualizing hydrocarbon groups, where $Z$ equals the parameter in the general empirical formula for hydrocarbons, $\mathrm{C}_{n} \mathrm{H}_{2 n+z}$. Thus, different classes of hydrocarbons can be distinguished by their mass spectral fragments. Certain masses due to inorganic compounds are removed (i.e., $\mathrm{H}_{2} \mathrm{O}, \mathrm{N}_{2}, \mathrm{O}_{2}, \mathrm{H}_{2} \mathrm{~S}, \mathrm{HCl}, \mathrm{CO}_{2}$, and $\mathrm{SO}_{2}$ ).

An average mass spectrum can be obtained for any pyrolysis temperature range of interest. This spectrum can be utilized to calculate a paraffin-napthene-aromatic (PNA) distribution by the technique of Robinson (1971). This is not the true composition of pyrolysis hydrocarbons, since a distinction between olefins and napthenes is not possible with this program. However, the PNA analysis is useful in separating pyrolysis samples into groups, which may then be considered in light of other geochemical or geologic factors. The average spectrum may also be used to calculate the quantitative factors introduced by
Patton et al. (in press) and utilized in this study (Table 4). The pyrolysis $S_{2}$ index $\left(\mathrm{PS}_{2}\right)$ is a quantitative measure of hydrocarbons released per microgram of sample over a given pyrolysis temperature range. It is related to $S_{2}$ (hydrocarbon source potential determined by RockEval analysis) and is a sensitive indicator of hydrocarbon generating potential. The pyrolysis hydrocarbon index $(\mathrm{PHI})$ normalizes the $\mathrm{PS}_{2}$ to the percentage OC, similar to the hydrogen index (HI) from RockEval. The average coefficient of variation for four replicate samples is $\pm 8.7 \%$. Replicate runs of samples are included in Table 4 .

\section{Gas Chromatography/Mass Spectrometry (GC/MS)}

Samples were extracted with methylene chloride and methanol (10: 1) in a Soxhlet apparatus for $48 \mathrm{hr}$. Extracts were concentrated by rotary evaporation and subsequently extracted with hexane. Hexane extracts were separated into saturate, aromatic, and NSO fractions by high-performance liquid chromatography (HPLC) using a bonded normal-phase column (Whatman Partisil PAC Magnum 9).

The GC/MS analyses were carried out on a Hewlett-Packard $5985 \mathrm{~A}$ quadrupole GC/MS/DS equipped with a $30 \mathrm{~m} \times 0.25 \mathrm{~mm}$ (ID) Durabond DB-5 (J\&W, Inc.) fused-silica column. The GC was programmed from 150 to $300^{\circ} \mathrm{C}$ at $4^{\circ} \mathrm{C} / \mathrm{min}$. and held at $300^{\circ} \mathrm{C}$ for $12.5 \mathrm{~min}$. Total analysis time was $50 \mathrm{~min}$. during which three masses $(57,191$, and 217) were monitored in the selected-ion mode (SIM) for 200 milliseconds each.

Phosphorus Analysis (total, inorganic, organic)

Two aliquots $(<1 \mathrm{~g})$ of dried sediment were analyzed for total and inorganic phosphorus using the extraction technique of Aspila et al. (1976). Total $\mathrm{P}$ is extracted from sediments with $1 \mathrm{~N} \mathrm{HCl}$ after ignition at $550^{\circ} \mathrm{C}$ for $2 \mathrm{hr}$. Inorganic $\mathrm{P}$ is leached with $1 \mathrm{~N} \mathrm{HCl}$ (without ignition of the sediment) and organic $\mathrm{P}$ is determined by difference. Phosphorus is detected as phosphate using the colorimetric technique of Murphy and Riley (1962) modified for higher P concentrations by Bray (1973, p. 149).

The phosphorus results are in Tables 2 and 3. The analytical precision of P standards is $\pm 1 \%$ for $20 \mu \mathrm{mol} \mathrm{P} / l$, with an average coefficient of variation of $\pm 1.3 \%$ at $15 \mu \mathrm{mol} / \mathrm{g}$, for four replicate samples. 

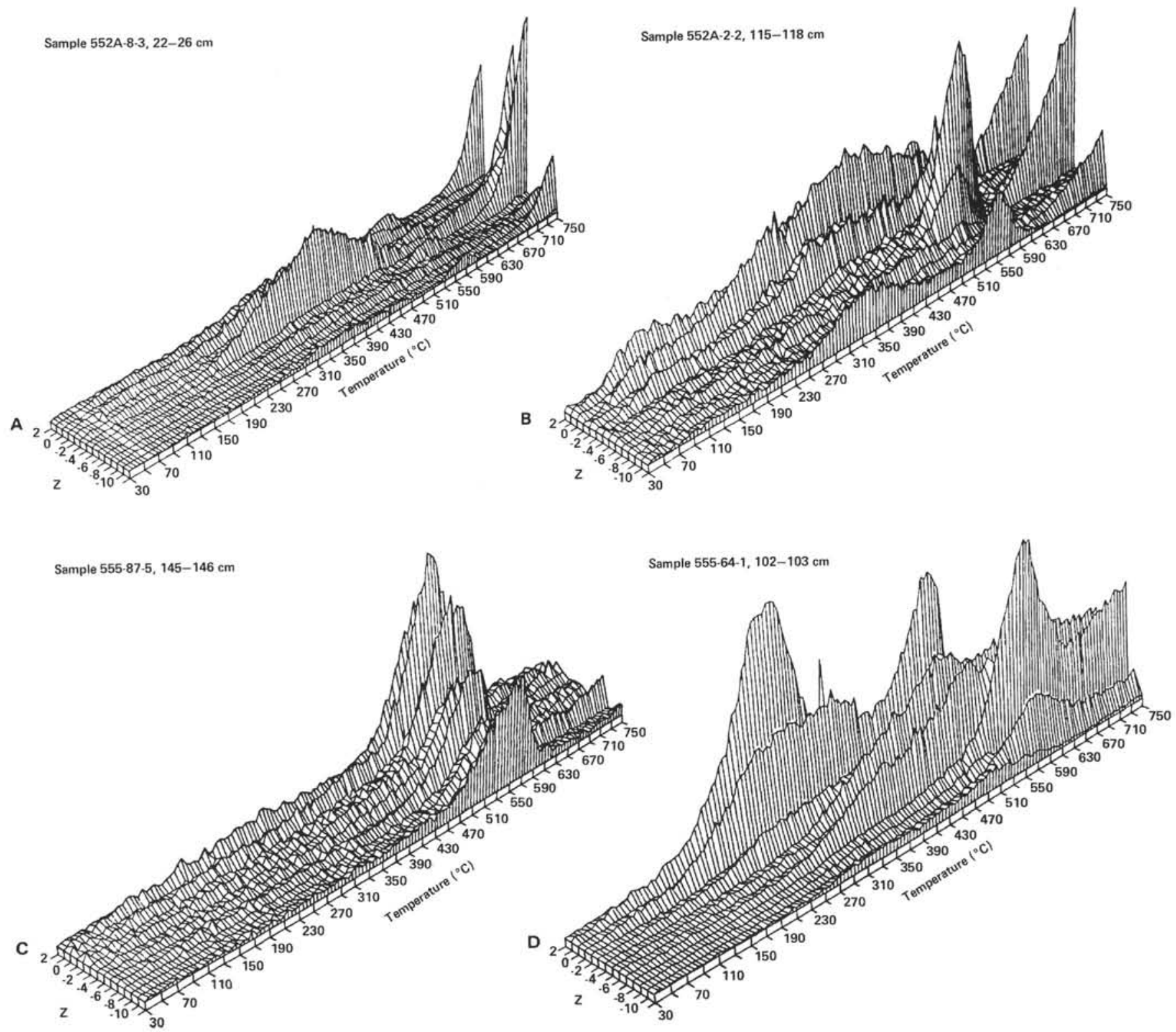

Figure 1. Pyrol/MS orthographic plot of hydrocarbon groups ( $Z$ values) versus temperature $\left({ }^{\circ} \mathrm{C}\right)$. A. Sample $552 \mathrm{~A}-8-3,22-26 \mathrm{~cm}$, a typical glacial sample. The relatively larger proportion of hydrocarbons released during high temperature cracking $\left(>600^{\circ} \mathrm{C}\right)$ of reworked $\mathrm{OM}$ is shown. $\mathrm{B}$. Sample 552A-2-2, 115-118 cm, a typical interglacial sample. The relatively larger proportion of immature, paraffin- and mononapthenic or olefinic $(\mathrm{z}=1$ and -1$)$ pyrolyzate hydrocarbons is shown. This is consistent with other geochemical data suggesting a more marine character of this OM. C. Sample 555-87-5, 145-146 cm. This sample is from lower-Paleocene (Unit IVb) sediment interbedded with lava flows. The pyrolyzate hydrocarbons show the mature nature of the kerogen (maximum generation at $560^{\circ} \mathrm{C}$ ). D. Sample $555-64-1,102-103 \mathrm{~cm}$. This sample is from lower-Paleocene (Unit IIIe) sediment without interbedded lava flows and shows a complex mixture of kerogen types and maturities from immature to postmature. E. Sample 553A-21-1, 125-126 cm. The early Eocene (Unit IVc) sample shows the relatively large proportion of paraffins $(Z$ $=1$ ) pyrolyzed from immature marine OM. This sample represents the low OC $(0.18 \%)$ oxidized-marine part of Phase 2 , episodic basinal shallowing and deepening. F. Sample 554A-5-5, 13-15 cm showing the immature, paraffin-prone nature of the OM (marine) and relative absence of reworked material. G. Sample 552-16-1, 10-14 cm showing the immature, paraffin-prone nature of the OM (marine) with some reworked OM. H. Sample 552-9-4, 112-114 cm showing the immature, marine nature of $\mathrm{OM}$ and decrease in reworked OM relative to Figure 1G, suggesting subsidence of source or sites of deposition.

Six samples yielded higher inorganic than total $\mathrm{P}$ and are noted in Tables 2 and 3. Morse and Cook (1978) reported similar results for some marine sediments. Other workers have reported incomplete recovery of total P in soils and lake sediments (Bornemisza and Igue, 1967; Sommers et al., 1970). Williams et al. (1970) found that the acid-extractable $\mathrm{P}$ concentration in highly weathered soil reached a maximum value at an ignition temperature of $250^{\circ} \mathrm{C}$ and then decreased at higher temperatures. Subsequent experiments indicated that this loss of $\mathrm{P}$ at higher ignition temperatures was not the result of volatilization of
P. Sommers et al. (1970) and Aspila et al. (1976) state that no serious loss of $\mathrm{P}$ occurs via oxidation and volatilization at $550^{\circ} \mathrm{C}$. Saunders and Williams (1955) and Bornemisza and Igue (1967) have suggested that the decrease in extractable $\mathrm{P}$ upon ignition results from formation of an aluminum-phosphate mineral phase which is less acid soluble. Because this discrepancy in extraction of inorganic and total P appears most serious in highly weathered soils, it is not surprising that the samples in our study that yield negative organic $\mathrm{P}$ contain primarily terrestrial and reworked materials. 

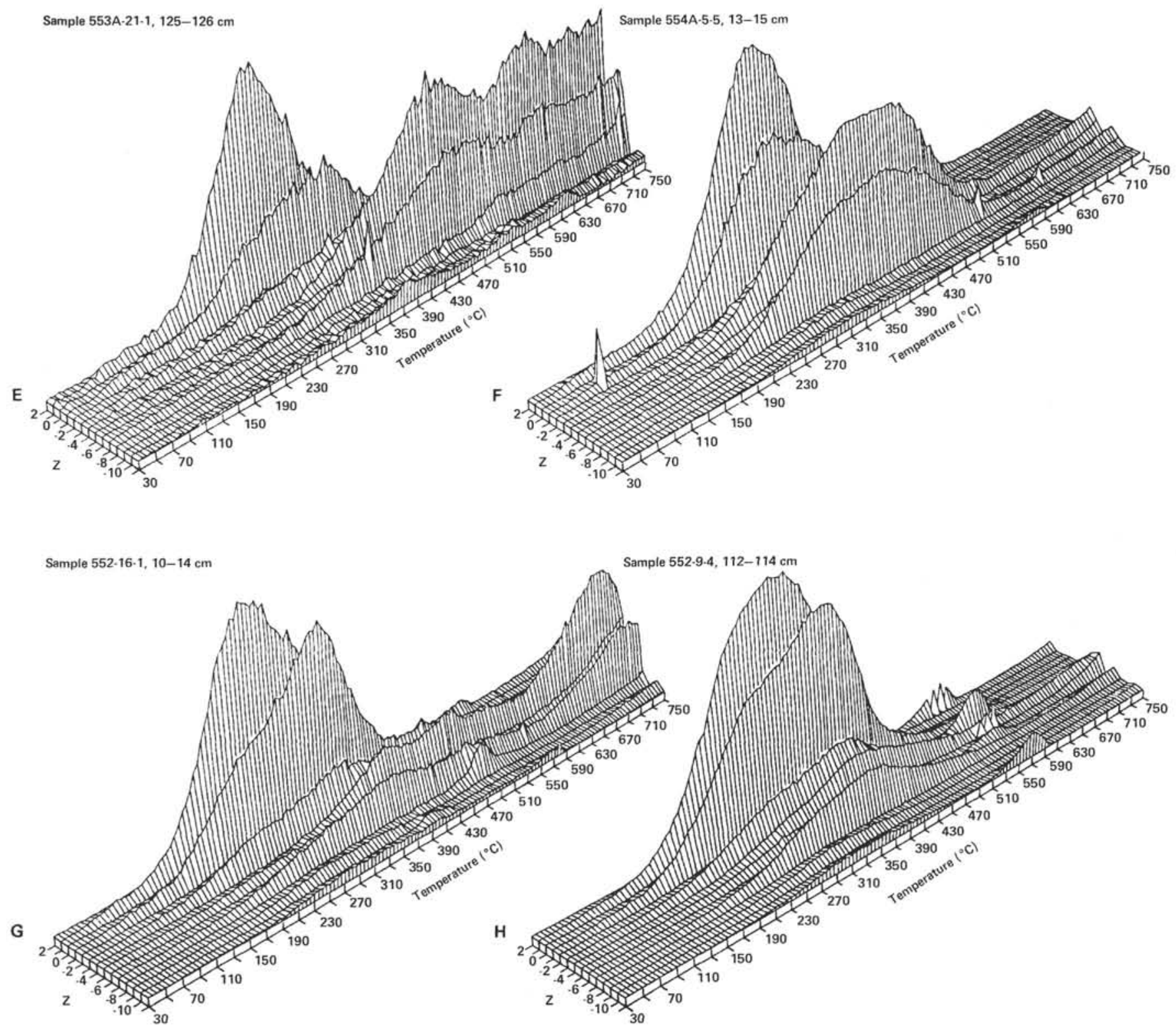

Figure 1. (Continued).

\section{Special Analytical Problems}

The low OC levels of many of the samples required that analytical methods be modified. Peters and Simoneit (1982) and Pedersen (1983) described some of the problems of total organic carbon (TOC) analysis of recent, high-carbonate, low-OC sediments ${ }^{3}$. Other potential problems include: (1) microquantities of components with high coefficients of variation, (2) sample inhomogeneity, and (3) contamination. We attempted to minimize these problems. Replicate samples were used to calculate maximum variability (this section) for each geochemical technique. Numerous blanks were run to check for contamination. Pyrol/ MS and Rock-Eval sample crucibles were repeatedly pyrolyzed to remove contamination. Quartz wool for packing samples in pyrol/MS crucibles was exhaustively extracted. Finally, interpretations are based on relative variations and integration of all data.

${ }^{3} \mathrm{HCl}$ treatment of sediments, often used to remove inorganic minerals (carbonates), can hydrolyze and solubilize immature $\mathrm{OM}$.

\section{RESULTS AND DISCUSSION}

\section{Pleistocene (glacial-interglacial cycles)}

Shipboard Rock-Eval pyrolysis and $(\mathrm{C} / \mathrm{N})_{\text {org }}$ ratios suggested possible differences in $\mathrm{OM}$ in Pleistocene glacial-interglacial sediments (site chapter, organic geochemistry section, Hole 553B, this volume). The inorganic data (Zimmerman et al., this volume) describe a "background" input of detrital quartz and feldspar throughout the sequence, with a greater abundance in the glacial muds. X-ray mineralogy shows different claymineral assemblages in glacial and interglacial periods. Continental biologic debris is also more abundant in glacial sediments. Rock-Eval analysis characterized both glacial and interglacial $\mathrm{OM}$ as highly oxidized with oxygen indices $(\mathrm{OI})$ greater than $700\left(\mathrm{mg} \mathrm{CO}_{2} / \mathrm{g} \mathrm{C}\right)$. How- 
Table 4. Pyrolysis/mass spectral data showing percent paraffins, napthenes, and aromatics $(\mathrm{P}, \mathrm{N}, \mathrm{A})$, and mono-, di-, and tricyclic napthenes $(\mathrm{M}, \mathrm{D}, \mathrm{T})$ for pyrolyzate hydrocarbons for various temperature ranges.

\begin{tabular}{|c|c|c|c|c|c|c|c|c|c|c|}
\hline \multirow{2}{*}{$\begin{array}{c}\text { Sample } \\
\text { (interval in } \mathrm{cm} \text { ) }\end{array}$} & & \multicolumn{3}{|c|}{$\begin{array}{c}\% \text { Paraffins }(\mathrm{P}), \% \text { napthenes }(\mathbb{N}) \text {, } \\
\% \text { aromatics }(\mathrm{A})^{\mathrm{a}}\end{array}$} & & \multicolumn{3}{|c|}{$\begin{array}{l}\% \text { Monocyclic (M), \% dicyclic (D), } \\
\% \text { tricyclic (T) napthenes }\end{array}$} & \multirow{2}{*}{$\frac{\mathrm{PS}_{2}{ }^{\mathrm{b}}}{200-600^{\circ} \mathrm{C}}$} & \multirow{2}{*}{$\frac{\mathrm{PHI}^{\mathrm{c}}}{200-600^{\circ} \mathrm{C}}$} \\
\hline & & $200-430^{\circ} \mathrm{C}$ & $300-500^{\circ} \mathrm{C}$ & $400-600^{\circ} \mathrm{C}$ & & $200-430^{\circ} \mathrm{C}$ & $300-500^{\circ} \mathrm{C}$ & $400-600^{\circ} \mathrm{C}$ & & \\
\hline \multirow{3}{*}{$\begin{array}{l}552 \mathrm{~A}-2-2,115-118 \\
\text { (interglacial) }\end{array}$} & $\mathrm{P}$ & 37.5 & 35.7 & 35.0 & $\mathrm{M}$ & 36.4 & 33.1 & 34.8 & \multirow[t]{3}{*}{0.38} & \multirow[t]{3}{*}{4.75} \\
\hline & $\mathrm{N}$ & 58.4 & 59.3 & 58.6 & D & 28.2 & 13.5 & 18.4 & & \\
\hline & A & 4.1 & 5.0 & 6.4 & $\mathrm{~T}$ & 35.2 & 53.4 & 46.7 & & \\
\hline \multirow{2}{*}{$\begin{array}{l}552 A-2-3,25-28 \\
\text { (glacial) }\end{array}$} & P & 36.7 & $\begin{array}{l}39.7 \\
57 .\end{array}$ & 27.5 & $\mathrm{M}$ & 40.2 & 37.3 & 46.2 & \multirow[t]{2}{*}{0.81} & \multirow[t]{2}{*}{4.05} \\
\hline & $\begin{array}{l}\mathrm{N} \\
\mathrm{A}\end{array}$ & $\begin{array}{r}60.3 \\
2.9\end{array}$ & $\begin{array}{r}57.9 \\
2.5\end{array}$ & $\begin{array}{r}70.1 \\
2.4\end{array}$ & $\stackrel{\mathrm{T}}{\mathrm{D}}$ & $\begin{array}{l}10.4 \\
49.2\end{array}$ & $\begin{array}{r}9.4 \\
53.1\end{array}$ & $\begin{array}{r}3.2 \\
50.4\end{array}$ & & \\
\hline \multirow{3}{*}{$\begin{array}{l}\text { 552A-8-3, 22-26 } \\
\text { (glacial) }\end{array}$} & P & 29.0 & 26.5 & 18.1 & $\mathrm{M}$ & 39.1 & 38.5 & 34.3 & \multirow[t]{2}{*}{0.64} & \multirow{3}{*}{4.00} \\
\hline & $\mathrm{N}$ & 68.2 & 71.0 & 79.4 & D & 14.6 & 8.0 & 17.6 & & \\
\hline & A & 2.7 & 2.6 & 2.5 & $\mathrm{~T}$ & 46.1 & 53.3 & 47.9 & 0.40 & \\
\hline \multirow{2}{*}{$\begin{array}{l}\text { 552A-8-3, 83-86 } \\
\text { (interglacial) }\end{array}$} & $\mathrm{N}$ & $\begin{array}{l}47.1 \\
48.6\end{array}$ & $\begin{array}{l}46.1 \\
44.5\end{array}$ & $\begin{array}{l}38.9 \\
51.1\end{array}$ & $\begin{array}{c}M \\
\text { D }\end{array}$ & $\begin{array}{l}29.6 \\
26.7\end{array}$ & $\begin{array}{l}11.4 \\
41.5\end{array}$ & $\begin{array}{r}0.0 \\
54.9\end{array}$ & 0.40 & 6.67 \\
\hline & A & 4.4 & 9.4 & 10.0 & $\mathrm{~T}$ & 43.6 & 46.9 & 45.0 & & \\
\hline $552-9-4,112-114$ & $\stackrel{P}{P}-2$ & 25.2 & 22.2 & 16.7 & $\mathrm{M}$ & 79.5 & 80.7 & 71.9 & 12.17 & 135.22 \\
\hline & $\mathrm{N}$ & 65.5 & 69.5 & 79.9 & $\stackrel{D}{D}$ & 9.6 & 8.4 & 14.2 & & \\
\hline $552-16-1,10-14$ & ${ }_{\mathrm{P}}^{A}$ & $\begin{array}{r}9.3 \\
41.4\end{array}$ & $\begin{array}{r}8.3 \\
24.0\end{array}$ & 3.4 & T & $\begin{array}{l}10.8 \\
79.5\end{array}$ & $\begin{array}{l}10.7 \\
88.5\end{array}$ & $\begin{array}{l}13.7 \\
44.6\end{array}$ & & \\
\hline & $\mathrm{N}$ & 50.3 & 69.8 & 86.2 & D & $\begin{array}{r}8.9 \\
8.9\end{array}$ & 2.0 & $\begin{array}{l}49.0 \\
12.1\end{array}$ & 4.52 & 26.59 \\
\hline & A & 8.4 & 6.2 & 2.7 & $\mathrm{~T}$ & 11.5 & 15.4 & 38.1 & & \\
\hline $553 \mathrm{~A}-21-1,125-126$ & $\mathrm{p}$ & 64.6 & 52.1 & 9.4 & $\dot{M}$ & 61.2 & 64.1 & 56.8 & 1.31 & 7.28 \\
\hline & $\mathrm{N}$ & 31.2 & 44.1 & 88.1 & $\mathrm{D}$ & 12.8 & 6.3 & 0.0 & & \\
\hline & A & 4.2 & 3.8 & 2.5 & $\mathrm{~T}$ & 25.9 & 29.4 & 43.1 & & \\
\hline $553 \mathrm{~A}-21-1,125-126$ & $P$ & 61.5 & 49.0 & 8.9 & M & 63.0 & 69.5 & 54.9 & 1.75 & 9.72 \\
\hline & $\mathrm{N}$ & 33.8 & 47.0 & 89.4 & D & 15.6 & 5.5 & 10.1 & & \\
\hline & A & 4.7 & 4.1 & 2.5 & $\mathrm{~T}$ & 21.3 & 24.8 & 34.8 & & \\
\hline $553 \mathrm{~A}-21-1,125-126$ & $\stackrel{P}{N}$ & $\begin{array}{l}68.0 \\
26.6\end{array}$ & $\begin{array}{l}52.0 \\
42.6\end{array}$ & $\begin{array}{l}17.3 \\
7796\end{array}$ & $\mathrm{M}$ & 57.1 & 67.3 & 43.3 & 1.63 & 9.06 \\
\hline & A & $\begin{array}{r}2.6 \\
5.5\end{array}$ & $\begin{array}{r}42.6 \\
5.5\end{array}$ & $\begin{array}{r}79.6 \\
3.1\end{array}$ & $\underset{T}{D}$ & $\begin{array}{r}9.7 \\
33.0\end{array}$ & $\begin{array}{r}0.7 \\
31.9\end{array}$ & $\begin{array}{l}0.0 \\
56.6\end{array}$ & & \\
\hline $553 \mathrm{~A}-21-1,125-126$ & $\ddot{\mathrm{p}}$ & 61.3 & 42.3 & 14.7 & $\dot{M}$ & 56.2 & 61.9 & 50.3 & 1.64 & 9.11 \\
\hline & $\mathrm{N}$ & 35.2 & 54.4 & 83.4 & D & 21.5 & 12.1 & 13.6 & & \\
\hline & A & 3.5 & 3.2 & 1.9 & $\mathrm{~T}$ & 22.1 & 25.9 & 35.9 & & \\
\hline $553 \mathrm{~A}-22-5,104-105$ & $P$ & 42.4 & 25.1 & 15.0 & M & 65.3 & 58.4 & 5.08 & 4.33 & 3.97 \\
\hline & $\mathrm{N}$ & 51.7 & 68.3 & 78.5 & $\mathrm{D}$ & 5.9 & 0.8 & 0.5 & & \\
\hline & A & 5.9 & 6.7 & 6.4 & $\mathrm{~T}$ & 28.6 & 40.7 & 48.6 & & \\
\hline $553 \mathrm{~A}-27-4,125-127$ & $P^{p}$ & $\begin{array}{l}33.2 \\
59.4\end{array}$ & 26.0 & $\begin{array}{l}12.5 \\
82.5\end{array}$ & M & $\begin{array}{r}70.7 \\
94\end{array}$ & 65.1 & 47.7 & 1.72 & 5.55 \\
\hline & N & $\begin{array}{l}59.4 \\
7.3\end{array}$ & $\begin{array}{r}66.6 \\
7.4\end{array}$ & $\begin{array}{l}82.5 \\
5.0\end{array}$ & $\stackrel{\mathrm{D}}{\mathrm{T}}$ & $\begin{array}{r}9.4 \\
198\end{array}$ & 9.9 & 21.9 & & \\
\hline $553 \mathrm{~A}-36-1,114-116$ & ${ }_{\mathrm{P}}^{\mathrm{A}}$ & $\begin{array}{r}7.3 \\
34.7\end{array}$ & 26.6 & 19.5 & M & $\begin{array}{l}19.8 \\
71.7\end{array}$ & $\begin{array}{l}24.9 \\
66.3\end{array}$ & $\begin{array}{l}30.3 \\
57.1\end{array}$ & 6.91 & 6.28 \\
\hline & $\mathrm{N}$ & 58.5 & 66.2 & 76.3 & $\mathrm{D}$ & 5.9 & 5.7 & 7.2 & & \\
\hline & A & 6.9 & 7.2 & 4.3 & $\mathrm{~T}$ & 22.2 & 27.9 & 35.6 & & \\
\hline 554A-5-5, 13-15 & $\vec{p}$ & 35.4 & 33.2 & 8.1 & M & 76.5 & 81.4 & 71.1 & 3.33 & 30.27 \\
\hline & N & 58.9 & 62.7 & 90.7 & $\mathrm{D}$ & 10.3 & 6.3 & 12.3 & & \\
\hline & A & 5.7 & 4.1 & 1.2 & $\mathrm{~T}$ & 13.0 & 12.1 & 16.5 & & \\
\hline 555-34-4, 137-138 & $P$ & 35.8 & 25.5 & & M & & 48.7 & 45.8 & 4.13 & 2.12 \\
\hline & N & 61.1 & 70.2 & 72.0 & $\stackrel{D}{D}$ & 27.8 & 12.9 & 14.7 & & \\
\hline $555-36-1,11-12$ & ${ }_{\mathrm{P}}^{A}$ & $\begin{array}{r}3.1 \\
39.8\end{array}$ & $\begin{array}{r}4.3 \\
34.5\end{array}$ & $\begin{array}{r}3.6 \\
27.2\end{array}$ & $\stackrel{\mathrm{T}}{\mathrm{M}}$ & $\begin{array}{l}26.1 \\
61.9\end{array}$ & $\begin{array}{l}38.3 \\
56.8\end{array}$ & $\begin{array}{l}40.2 \\
50.7\end{array}$ & 2.46 & 3.46 \\
\hline & $\mathrm{N}$ & 57.3 & 63.0 & 70.9 & D & 3.3 & 4.7 & 0.2 & & \\
\hline & A & 3.0 & 2.4 & 1.9 & $\mathrm{~T}$ & 34.7 & 38.4 & 48.9 & & \\
\hline $555-40-5,138-139$ & $\hat{\mathrm{P}}$ & 43.7 & 23.6 & 11.4 & $M$ & 73.7 & 66.8 & 53.4 & 2.44 & 2.60 \\
\hline & $\mathrm{N}$ & 52.2 & 73 & 86.5 & D & 0.0 & 0.0 & 0.0 & & \\
\hline & A & 4.1 & 2. & 2.1 & $\mathrm{~T}$ & 26.2 & 33.1 & 46.2 & & \\
\hline $555-40-5,138-139$ & $P$ & 37 & 31.4 & & M & 70.8 & 66 & 52.3 & 2.24 & 2.38 \\
\hline & $\mathrm{N}$ & 59.3 & 66.2 & 74.1 & D & 5.9 & 10.2 & 22.6 & & \\
\hline & $A$ & $\begin{array}{r}3.0 \\
51.3\end{array}$ & $\begin{array}{r}2.4 \\
3.4\end{array}$ & 1.9 & $\mathrm{~T}$ & 23.2 & $\begin{array}{l}23.1 \\
68.0\end{array}$ & 24.9 & & \\
\hline $555-64-1,102-103$ & P & $\begin{array}{l}51.3 \\
44.0\end{array}$ & $\begin{array}{l}38.4 \\
56.3\end{array}$ & $\begin{array}{l}27.4 \\
69.2\end{array}$ & $M$ & 71.8 & $\begin{array}{l}68.0 \\
62\end{array}$ & $\begin{array}{l}53.7 \\
14.4\end{array}$ & 1.74 & 1.91 \\
\hline & N & $\begin{array}{r}44.0 \\
4.7\end{array}$ & $\begin{array}{c}56 \\
5\end{array}$ & $\begin{array}{r}69.2 \\
3.3\end{array}$ & $\stackrel{D}{\mathrm{D}}$ & $\begin{array}{l}11.3 \\
16.8\end{array}$ & $\begin{array}{r}6.2 \\
25.7\end{array}$ & $\begin{array}{l}14.4 \\
31.6\end{array}$ & & \\
\hline $555-87-5,145-146$ & ${ }_{\mathrm{P}}^{\mathrm{A}}$ & 26.8 & 18 & & $\begin{array}{l}1 \\
M\end{array}$ & $\begin{array}{l}16.8 \\
51.7\end{array}$ & 38.4 & $\begin{array}{l}21.6 \\
26.9\end{array}$ & 6.42 & 2.38 \\
\hline & $\mathrm{N}$ & 63.4 & 67 & 71.3 & D & 0.0 & 0.0 & 0.0 & & \\
\hline & A & 9.8 & 13 & 14.2 & $\mathrm{~T}$ & 48.2 & 61.5 & 73.0 & & \\
\hline $555-92-2,148-150$ & $P$ & 28. & 18 & 21.1 & $\dot{M}$ & 51.9 & 34. & 44.0 & 2.21 & 3.30 \\
\hline & $\mathrm{N}$ & 62.0 & 74.6 & 74.4 & D & 12.5 & 0.0 & 11.5 & & \\
\hline & A & 9.4 & 6.8 & 4.4 & $\mathrm{~T}$ & 35.4 & 65.2 & 44.3 & & \\
\hline
\end{tabular}

Note: Also shown is the pyrolysis $S_{2}$ index, $\mathrm{P} S_{2}$, and pyrolysis hydrocarbon index $\mathrm{PHI}$.

These values do not represent the true pyrolysis products, since olefins are not differentiated from napthenes by the mass spectrometer or the

Robinson (1971) computer program. The data are used for relative comparison of pyrolysis samples.
$\mathrm{PS}_{2}$ is the sum of intensities of masses representative of paraffins $(43+57+71)$, monocyclic napthenes $(41+55+69)$, and aromatics $(91$ $+141+191$ ) per microgram $(\mu \mathrm{g})$ of sample. PS 2 is adjusted to a daily instrument response factor calculated with a "standard" sample.

${ }^{\mathrm{C}} \mathrm{PHI}$ is $\mathrm{PS} 2$ divided by the percentage organic carbon of the sample.

ever, additional organic geochemical data (organic $\mathrm{P}$, pyrol/MS, GC/MS, and \% RC) indicate that a greater proportion of OM in the interglacial sediments is of marine origin. Conversely, the glacial sediments primarily contain terrestrial and/or reworked OM. This is plausible since carbonate-rich interglacial sediments result from increased productivity of calcareous organisms.

Organic carbon and $\mathrm{CaCO}_{3}$ percentages differentiate the three phases of glacial-interglacial cycles (Fig. 2). The glacial muds $\left(5-20 \% \mathrm{CaCO}_{3}\right)$ have $\mathrm{OC}$ values from $0.14-0.20 \%$, the interglacial oozes $\left(70-90 \% \mathrm{CaCO}_{3}\right)$ range from $0.06-0.08 \% \mathrm{OC}$, and the transitional marls $\left(20-70 \% \mathrm{CaCO}_{3}\right)$ have intermediate $\mathrm{OC}$ values of 0.08 $0.16 \%$. Figure 2 shows the roughly inverse relationship of $\mathrm{OC}$ to $\mathrm{CaCO}_{3}$. During glacial and transitional peri- ods, higher OC levels could result from greater influx of resistant, land-derived OM during low sea level stands. Lower carbonate levels could result from decreased productivity by calcareous organisms and dilution by detrital material. Dissolution of carbonates is probably not significant here (Zimmerman et al., this volume).

Glacial-interglacial cycles cannot be distinguished by visual kerogen analysis. However, all samples contain reworked, land-derived, resistant detritus (fusinite and vitrinite). Most samples contain amorphous matter believed to be bacterially degraded. Bacterially degraded amorphous matter is distinguishable by its grainy appearance, which is due to numerous perforations. The perforations are often dark rimmed, circular or rod shaped, less than $2 \mu \mathrm{m}$ in size, and thought to be bacte- 


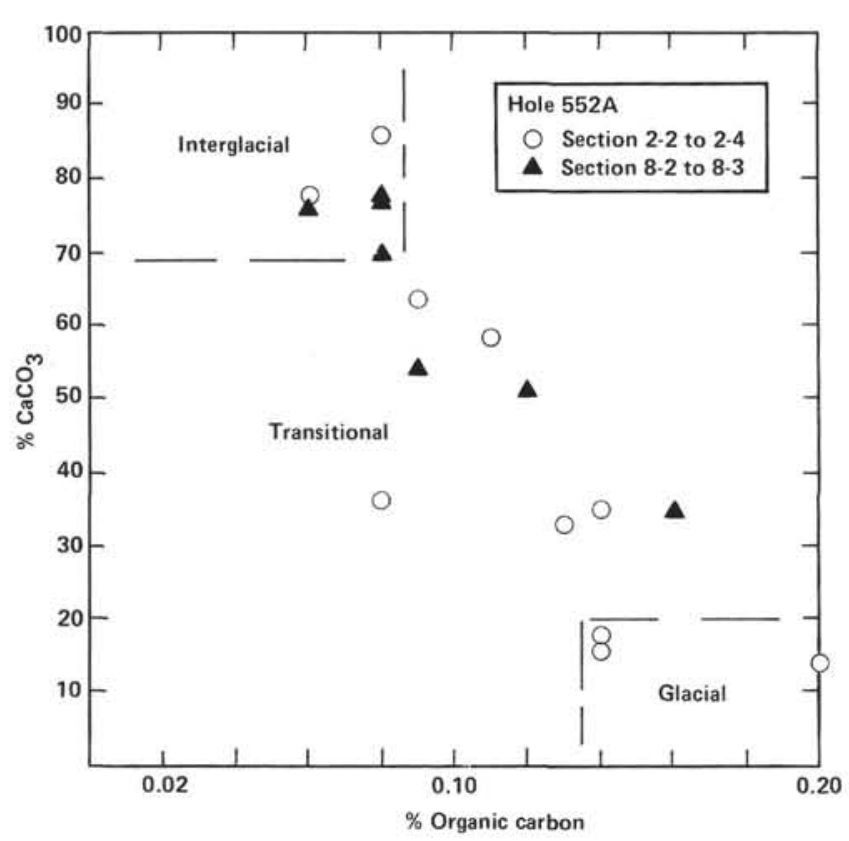

Figure 2. $\mathrm{CaCO}_{3}$ versus $\mathrm{OC}$ for Pleistocene glacial-interglacial samples from Cores 552A-2 and 552A-8, showing a roughly inverse relationship. The three phases of glacial-interglacial cycles (glacial, interglacial, and transitional) can be distinguished on the basis of $\mathrm{OC}$ and $\mathrm{CaCO}_{3}$ percentage composition.

rial artifacts. Fecal pellets, fungal remains, and plant cuticle were observed intermittently. The latter two are probably reworked. Fecal pellets may represent a marine contribution. Palynomorphs in glacial Samples 552A$2-3,25-28 \mathrm{~cm}$ (pine pollen) and 552A-2-3, 5-8 cm (trilete spore) are probably reworked from older rocks (Tertiary?) as indicated by their color. Only spores and resin particles showed a possible correlation to increased input of terrestrial OM during glacial periods. There is evidence, however, that acid maceration during the preparation of kerogen for visual analysis can hydrolyze a significant part of immature OM (Roberts et al., 1973; Peters and Simoneit, 1982).

Rock-Eval data for whole-sediment samples are summarized in Table 2. Because of the very low levels of OC $(0.06-0.20 \%)$ and the highly oxidized nature of the OM, only $S_{3}$ and percentage RC values are tabulated. We believe the percentage RC to be diagnostic of the phases of glacial-interglacial cycles (Fig. 3). The glacial muds, with higher OC, also have relatively larger RC values $(70-83 \%)$. In contrast, interglacial oozes, with lower OC, have lower RC values $(55-71 \%)$. The transitional marls have $\mathrm{RC}$ values from $58-80 \%$. The percentage RC values apparently reflect greater input of resistant-detrital OM during the glacial periods. This correlates with detrital mineralogy change during the cycles (Zimmerman et al., this volume). Glacial phases contain more detrital quartz and feldspar, terrestrial clays, and reworked OM due to larger shelf areas exposed to erosion.

Rock-Eval data also indicate that there is no significant inorganic carbonate contribution to the $S_{3}$ peak. Figures 4 and 5 show the direct relationship of $S_{3}$ to OC and the inverse relationship to carbonate content. This suggests an organic source for $\mathrm{S}_{3} \mathrm{CO}_{2}$. In addition, comparison of PC to OC could alert workers to instances of significant inorganic $\mathrm{CO}_{2}$.

A Pyrol/MS orthographic plot of a typical glacial sample (Fig. 1A) shows the large proportion of hydrocarbons released during high-temperature cracking $\left(>600^{\circ} \mathrm{C}\right)$ from residual OM. A typical interglacial sample (Fig. 1B) yields a larger proportion of pyrolyzate hydrocarbons from immature OM. Table 4 gives pyrolyzate hydrocarbon yields in the $200-600^{\circ} \mathrm{C}$ range for glacial (Samples 552A-2-3, 25-28 cm and 552A-8-3, 22-26 $\mathrm{cm}$ ) and interglacial (Samples 552A-2-2, 115-118 cm and 552A-8-3, 83-86 cm) samples. Although glacial cores have higher $\mathrm{PS}_{2}$ values (average 0.73 ) than interglacial cores (average 0.39 ), when normalized to amount of OC present, the PHI is greater for interglacial samples (average 5.73) than for glacial samples (average 4.03). This suggests that interglacial sediments contain a greater proportion of immature, lipid-rich, marine OM consistent with percentage $\mathrm{RC}$ results.

The saturate portion of bitumen extracted from composites of glacial and interglacial samples was analyzed by GC/MS for "biomarkers." Biomarker materials in living organisms and recent sediments are dominantly oxygenated rather than hydrocarbon species (MacKenzie et al., 1982), which would not be isolated in the saturate portion of the extract. The interglacial composite yielded no hydrocarbon biomarkers. The glacial composite yielded only minute amounts of sterane and triterpane biomarkers. The triterpanes indicate a maturation for this glacial composite (Table 5) which is inconsistent with its geologic age and burial temperature. However, the geochemical data show that the major part of glacial samples consists of reworked, inert material as verified by the pyrol/MS plot (see Fig. 1A) and RC $(\approx 80 \%)$ from Rock-Eval pyrolysis. MacKenzie et al. (1980) have shown that reworked material can interfere with biomarker estimates of maturity and often result in overly mature evaluations. The inability to extract significant amounts of biomarker hydrocarbons from these low OC samples $(<0.2 \%)$ could be the result of their oxidized or immature nature.

The phosphorus data for glacial-interglacial sediments are given in Table 2 and Figures 3 and 6A. Organic P levels in Pleistocene samples are highest for interglacial periods [average $(\mathrm{C} / \mathrm{P})_{\text {org }}=19$ ] and decrease to nondetectable during glacial periods. Marine $\mathrm{OM}$ has an average mole ratio of $(\mathrm{C} / \mathrm{P})_{\text {org }}=106$ ("Redfield ratio," Redfield et al., 1963). Terrestrial OM, recent and reworked, can have $(\mathrm{C} / \mathrm{P})_{\text {org }}$ ratios greater than 500 (Gjessing, 1976; Nissenbaum, 1979; and Sandstrom, 1982). This ratio may be a good indicator of source of OM (Lyons and Gaudette, 1979; Nissenbaum, 1979; and Sandstrom, 1982). Froelich et al. (1982) showed higher (C/ $\mathrm{P})_{\text {org }}$ ratios relative to the Redfield ratio in organic-rich sediments $(>1.0 \%)$ and lower ratios in organic-poor, oxidizing, pelagic sediments $(<0.5 \%)$. These workers also discuss increased $\mathrm{P}$ levels associated with biogenic calcareous tests. Carter (1978) and Carter and Mitterer (1978) describe the association of oxygen-enriched OM with calcium carbonates, as part of the skeletal organic 


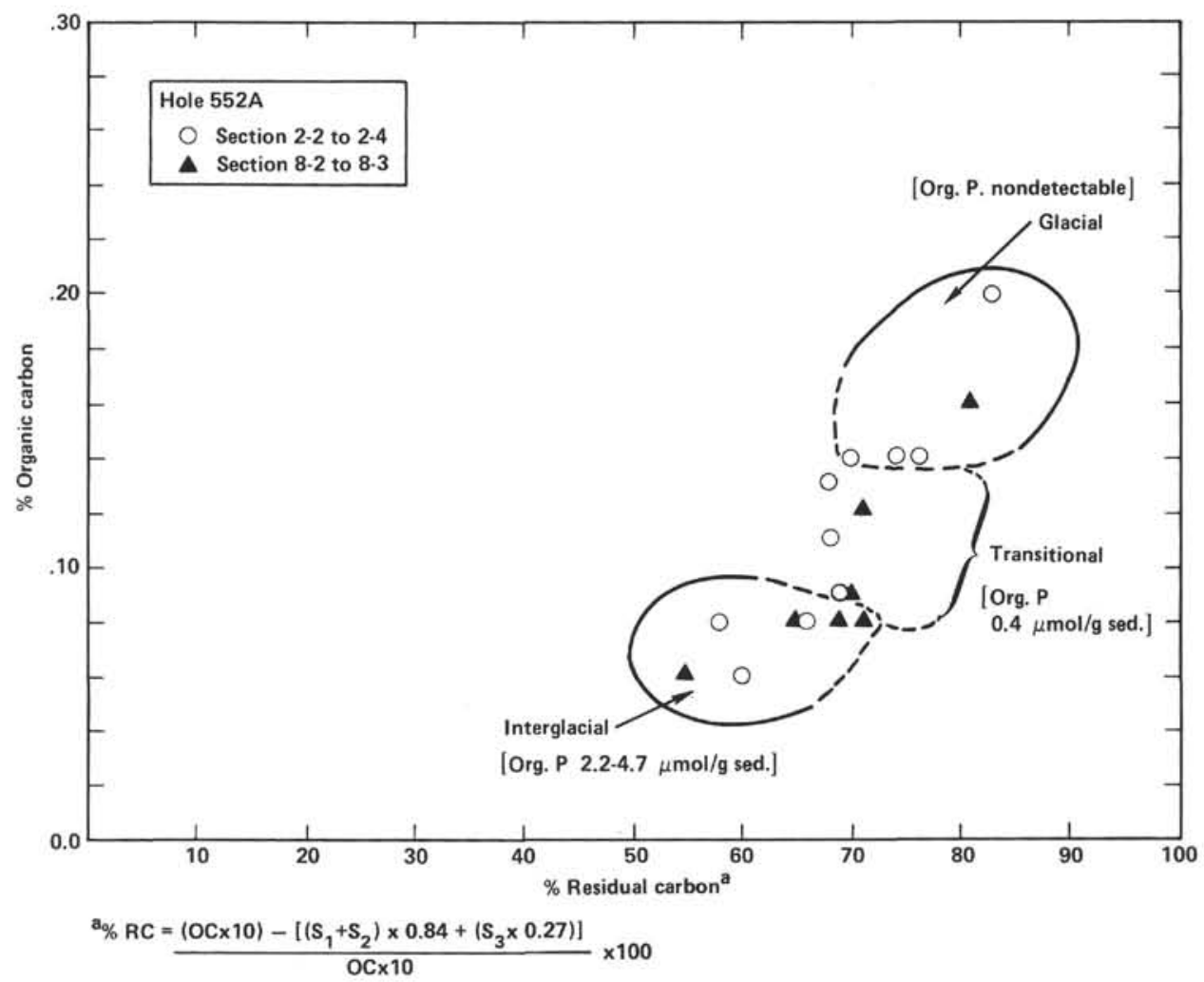

Figure 3. OC versus residual carbon (RC) for Pleistocene glacial-interglacial samples from Cores 552A-2 and 552A-8, showing the larger proportion of RC in glacial versus interglacial samples. This RC probably results from reworked-detrital OM, and the higher percentage is due to increased erosion and decreased productivity by calcareous organisms.

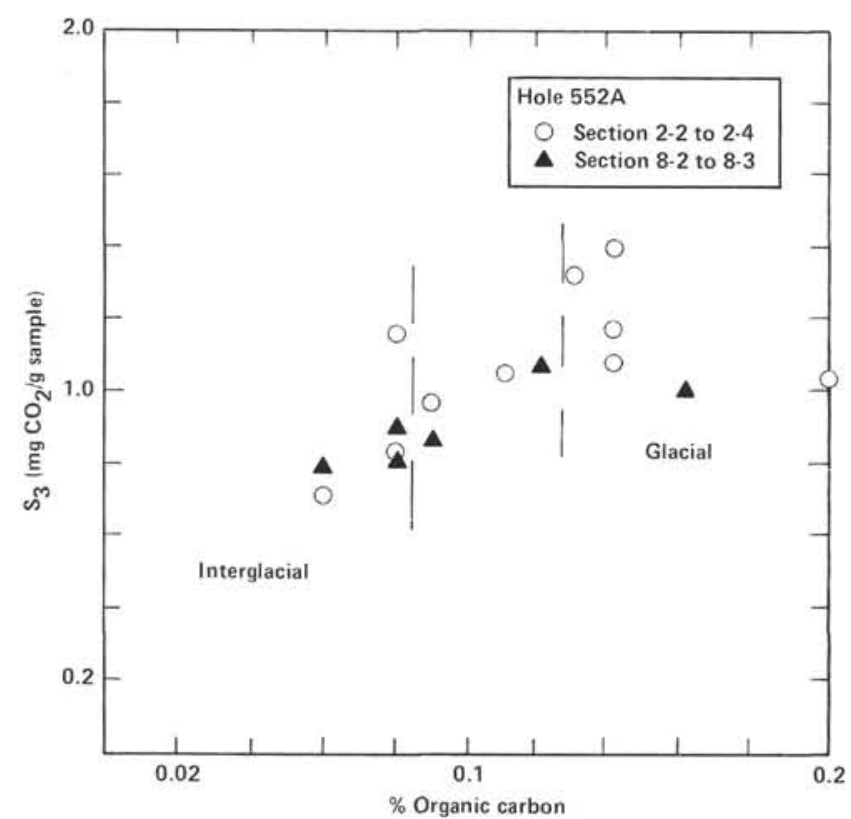

Figure 4. Rock-Eval $S_{3}$ peak $\left(<390^{\circ} \mathrm{C} \mathrm{CO}_{2}\right)$ versus OC for Pleistocene glacial-interglacial samples from Cores 552A-2 and 552A-8, showing the direct relationship of $S_{3}$ to OC, which suggests the lack of an inorganic carbonate contribution to $S_{3}$.

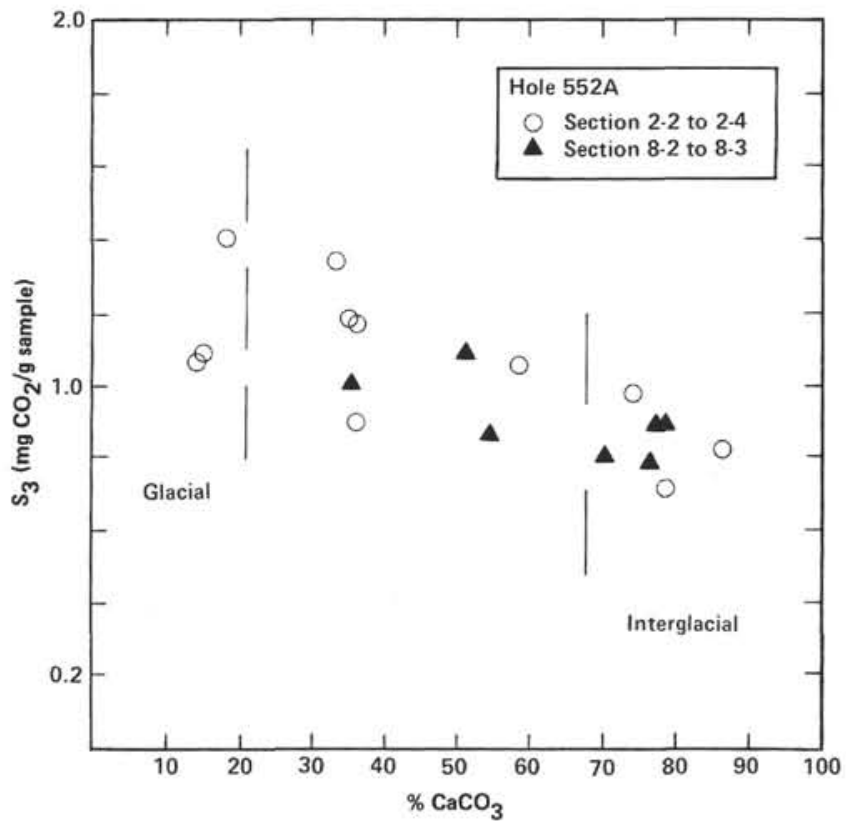

Figure 5. Rock-Eval $\mathrm{S}_{3}$ peak $\left(<390^{\circ} \mathrm{C} \mathrm{CO}_{2}\right)$ versus $\mathrm{CaCO}_{3}$ for Pleistocene glacial-interglacial samples from Cores 552A-2 and 552A-8, showing the inverse relationship of $\mathrm{S}_{3}$ to $\mathrm{CaCO}_{3}$, which suggests the lack of an inorganic carbonate contribution to $S_{3}$. 
Table 5. GC/MS biomarker ratios of selected Leg 81 samples.

\begin{tabular}{|c|c|c|c|c|}
\hline \multirow[b]{3}{*}{ Sample (interval in $\mathrm{cm}$ ) } & \multicolumn{2}{|c|}{ Hopane maturation } & \multicolumn{2}{|c|}{ Sterane environment ${ }^{\mathrm{a}}$} \\
\hline & $(30+31 \mathrm{R}+31 \mathrm{~S}) \alpha, \beta^{b}$ & $\%$ & $29 \mathrm{R}$ & (terrestrial) \\
\hline & $(30+31) \beta . \beta$ & $(22 S+22 R$ & $27 R$ & (marine) \\
\hline $552 \mathrm{~A}-2-3,5-8$ glacial & & & & \\
\hline $552 \mathrm{~A}-2-3,25-28$ composite & 2.10 & 48.0 & & - \\
\hline $553 \mathrm{~A}-21-1,125-126$ & 2.53 & 50.6 & & 1.97 \\
\hline $553 \mathrm{~A}-24-1,23-24$ & 5.40 & 48.1 & & 1.91 \\
\hline $553 \mathrm{~A}-36-1,11-12$ & 0.73 & 33.0 & & 1.36 \\
\hline $553 \mathrm{~A}-37-4,123-125$ & 1.04 & 41.6 & & 2.06 \\
\hline $555-40-5,138-139$ & 2.61 & 51.1 & & 1.38 \\
\hline $555-64-3,117-118$ & - & - & & - \\
\hline $555-92-2,148-150$ & 3.36 & 59.0 & & - \\
\hline
\end{tabular}

matrix of biogenic carbonates and as adsorbed $\mathrm{OM}$ on biogenic and nonbiogenic carbonates. They believe this association is related to the geometric similarity between carboxyl groups of $\mathrm{OM}$ and carbonate anions. Thus, organic $\mathrm{P}$ in interglacial sediments suggests highly oxidized marine $\mathrm{OM}$, whereas the absence of organic $\mathrm{P}$ in glacial sediments suggests reworked and/or terrestrial OM.

Carbon-isotope data for glacial-interglacial kerogen (Table 2) show no significant variations. Carbon isotopes are often used to indicate relative changes in the content of terrestrial or marine OM (Rashid and Reinson, 1979; Erdman and Schorno, 1980). Galimov et al. (1980) reported $\delta^{13} \mathrm{C}$ values from -22.6 to $-24.9 \%$ for carbonized, higher plant matter, while noncarbonized terrestrial detritus is lighter, -28 to $-30 \%$. The carbon-isotope values for the glacial-interglacial samples (average $\delta^{13} \mathrm{C}=-24.4 \%$ ) probably reflect the large proportion of residual/reworked OM, with values similar to those of Galimov et al. (1980).

The carbonate-carbon and carbonate-oxygen isotopic data, also shown in Table 2, indicate variations between glacial-interglacial periods, which apparently become less dramatic with depth. Inorganic isotopes are being studied by others (Zimmerman et al., this volume).

\section{Miocene-Late Pliocene}

The Miocene-late Pliocene sediments for all sites will be discussed collectively because their organic geochemistry is similar. These pelagic, biogenic, calcareous sediments (oozes to chalks) were deposited at depths similar to their modern analogs. Carbonate content is greater than $80 \%$, with minor amounts of detrital quartz, clays, and biosiliceous materials (site chapters, this volume). Organic geochemical results are given in Table 3 for selected Plio-Miocene samples (Samples 552-6-3, 112-114 $\mathrm{cm}, 552 \mathrm{~A}-36-1,2-3 \mathrm{~cm}, 554 \mathrm{~A}-5-2,5-7 \mathrm{~cm}, 555-15-1$, $140-141 \mathrm{~cm}, 555-25-5,130-131 \mathrm{~cm})$ and in Figure 6. The organic geochemical and visual kerogen data indicate that the OM in these high-carbonate, pelagic sediments is a mixture of oxidized-marine and terrestrial detritus.

The OC values for these samples are less than $0.08 \%$, typical of oxidized, deep-ocean sediments. Visual kerogen analysis rates four Miocene samples (Table 1) as "very lean," with some fusinite and vitrinite present.
These samples also contain some grainy (perforated) amorphous matter, believed to be bacterially degraded. Other identifiable OM includes: Sample 552A-36-1, 2-3 $\mathrm{cm}$, trilete (fern) spore, reworked (early Tertiary or older), Sample 555-25-5, 130-132 cm, monosulcate pollen grain (palm), reworked, and fungal remains. The organic C/P ratios (average $=19$ ) for Miocene samples (Table 3) suggest a highly oxidized, marine component of $\mathrm{OM}$ (Froelich et al., 1982), probably deposited with biogenic carbonates as discussed in the section on Pleistocene interglacial sediments. Organic $\mathrm{C} / \mathrm{N}$ ratios of Plio-Miocene sediments (Table 3, Fig. 6A-D and site chapters, this volume) range from 5 to 13 . This is the normal range for marine organisms and $\mathrm{OM}$ in marine sediments (Nissenbaum, 1979; Rashid and Reinson, 1979; Waples and Sloan, 1980; Peters et al., 1981). The average $\delta^{13} \mathrm{C}$ value for Plio-Miocene $\mathrm{OM}$ is $-25.4 \%$ (range -24.4 to $-26.8 \%$ ). These values suggest a marine/terrestrial mixture (Rashid and Reinson, 1979; Erdman and Schorno, 1980; Patton et al., in press), although reworked $\mathrm{OM}$ may have similar $\delta^{13} \mathrm{C}$ values (Galimov et al., 1980).

\section{Paleocene-Oligocene}

Paleocene-Oligocene sedimentary OM will be discussed in the context of the geologic history of the isolation of Rockall from Greenland (Phases 1-3) described by Roberts et al. (this volume).

Phase 1 (igneous phase) is characterized by basaltic lava flows and tuff beds, with minor nonvolcanic sediment interbeds. Site 555 , located midway between the Hatton and Edoras topographic "highs" in the HattonRockall Basin, is a major site of deposition during this phase (site chapter, this volume). The only OM recovered for study from this Paleocene phase is from Site 555 , Unit IVb. Sedimentary and biologic data suggest a shallow marine environment with major continental input (site chapter, this volume).

Organic geochemical and visual kerogen data suggest primarily terrestrial OM in Unit IVb, Site 555. In addition, there is evidence of thermal maturation of $\mathrm{OM}$ as a result of volcanic activity. The average OC content is $1.1 \%$ (range $0.44-2.70 \%$ ) for five samples from this unit (Table 6). The carbon isotope, $(\mathrm{C} / \mathrm{P})_{\text {org }}$, and RockEval data (Tables 3 and 6, Fig. 6D, and site chapter, this volume) indicate terrestrial $\mathrm{OM}$. The organic $\mathrm{C} / \mathrm{N}$ ratio increases relative to marine $\mathrm{OM}$ (average $\mathrm{C} / \mathrm{N} \approx 10$, Waples and Sloan, 1980) with increasing amounts of terrestrial OM (Rashid and Reinson, 1979; Peters et al., 1981) and with thermal maturation (Waples, 1977; Chung and Sackett, 1979; Nissenbaum, 1979; Peters et al., 1981, 1983). The average $\mathrm{C} / \mathrm{N}$ for these samples is 44 , range 32.7 to 52.5 (Table 6 and Fig. 6D), indicative of terrestrial OM.

Several workers have demonstrated thermal effects of intrusions on DSDP sediments (Simoneit et al., 1981; Peters et al., 1983). We did not attempt this type of detailed study because of the limited occurrence of sediments and complexity of the sediment/volcanic lithology (site chapter, this volume). However, the maturity of the OM in several of these samples is inconsistent with 

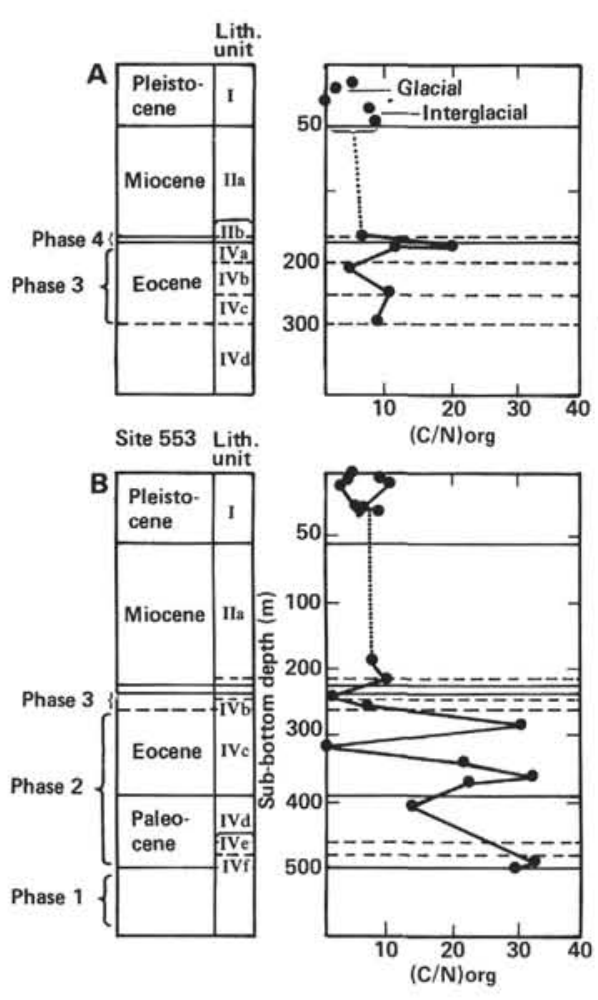
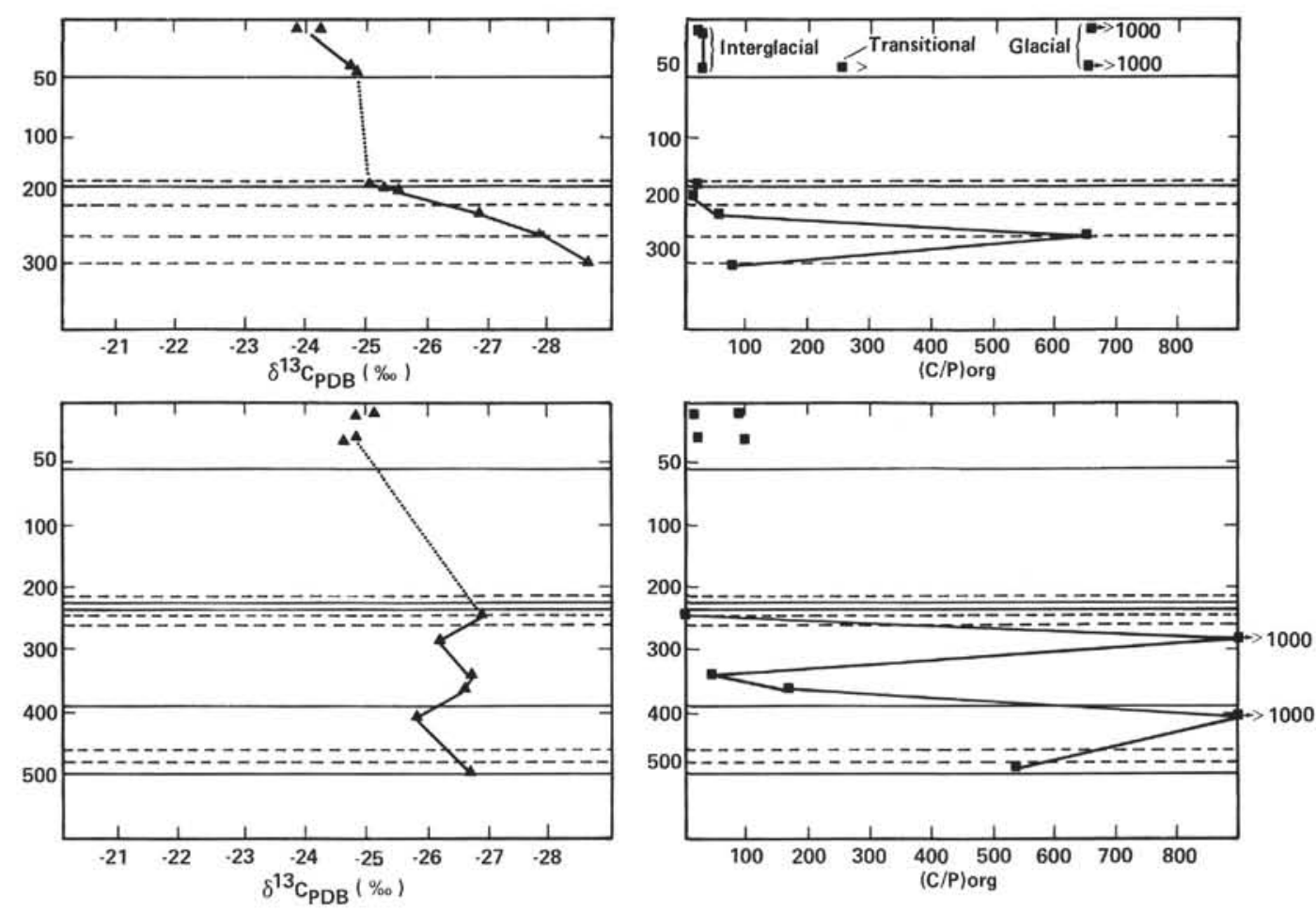

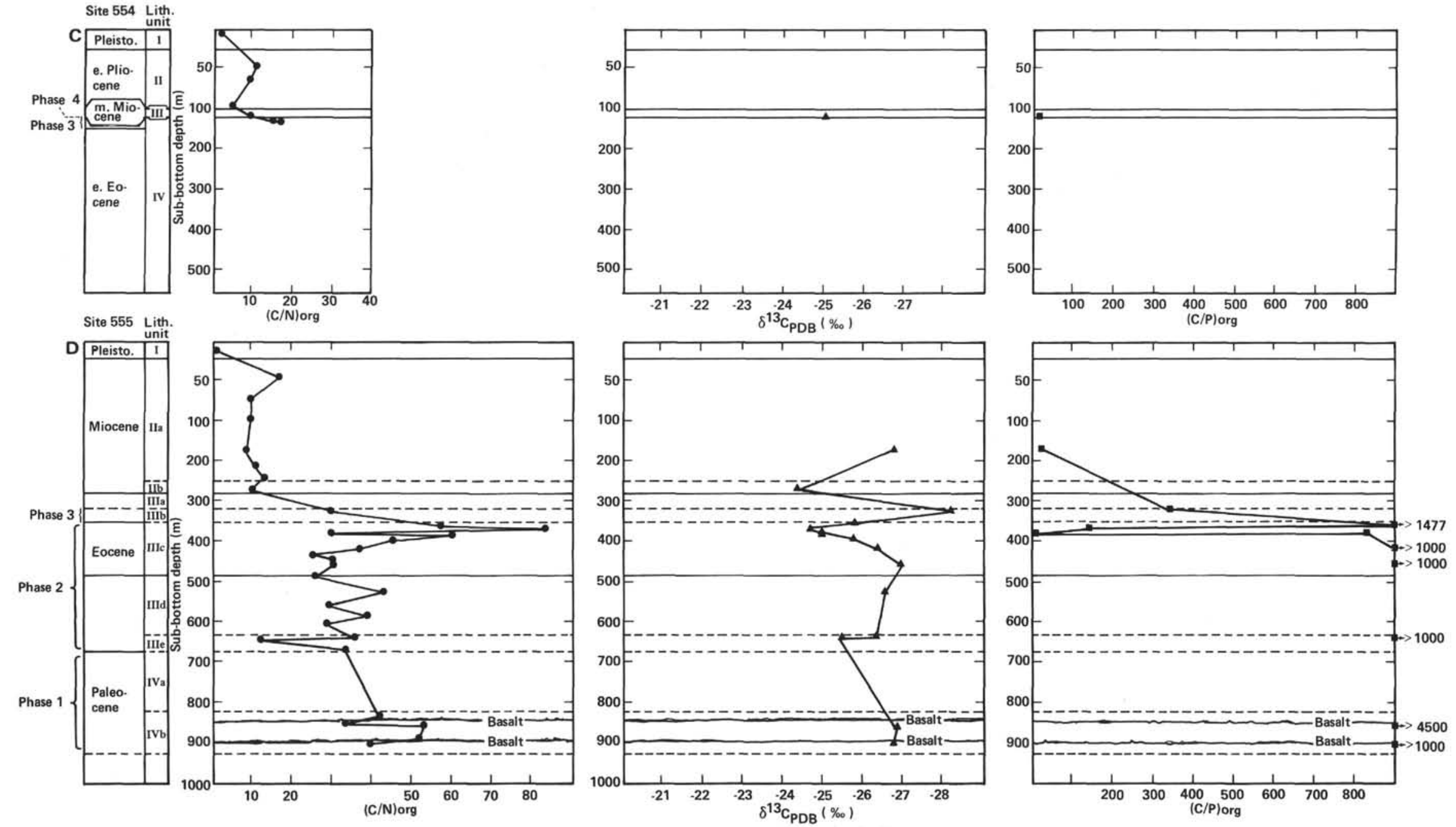

Figure 6. Organic geochemical data [atomic $(\mathrm{C} / \mathrm{N})_{\text {org }}$ and $(\mathrm{C} / \mathrm{P})_{\text {org }}$ ratios and carbon isotopes $\left(\delta^{13} \mathrm{C} \%\right.$ ) of kerogen] versus geologic age, lithologic unit, and sub-bottom depth (m). A. Site 552 : $(\mathrm{C} / \mathrm{P})_{\text {org }}$ values indicate the marine nature of interglacial samples. The $\delta^{13} \mathrm{C}$ values suggest the increasing marine character of OM as Site 552 subsides during Phase 3. B. Site 553. C. Site 554. D. Site 555: $(\mathrm{C} / \mathrm{N})_{\text {org }}$ values indicate pulses of terrestrial OM, probably resulting from episodic changes in depth of deposition (shallowing) during Phase 2. 


\section{A. J. KALTENBACK ET AL.}

Table 6. Rock-Eval pyrolysis and atomic $(\mathrm{C} / \mathrm{N})$ org data for whole-sediment samples from Leg 81 Site 555, Units IIIe and IVb.

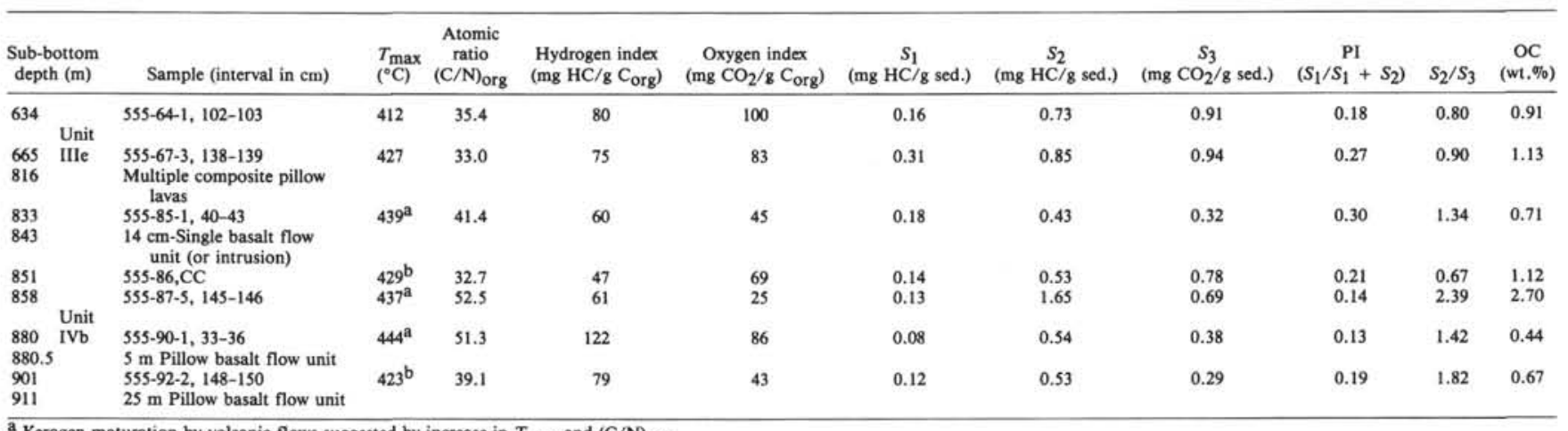

b ${ }_{\mathrm{T}}$ max of $\mathrm{S}_{2}$ can be affected by the "heavy-fraction" of bitumen hydrocarbons released in the $350-450^{\circ} \mathrm{C}$ range (Clementz, 1979). Rock-Eval pyrograms and production indices (PI) suggest the observed $\mathrm{T}_{\max }$ of these samples may be decreased by this effect.

the known thermal gradient. The pyrol/MS orthographic plot in Figure 1C shows the mature nature of the kerogen (maximum hydrocarbon generation $\approx 560^{\circ} \mathrm{C}$ ) and the relative simplicity of the pyrolyzate compared to overlying, Unit IIIe, sediments (Fig. 1D). The pyrol/MS PNA data (Table 4) show higher contents of aromatic and tricyclic pyrolyzate components for Sample 555$87-5,145-146 \mathrm{~cm}$ relative to the immature sample, Sample 555-64-1, 102-103. This is indicative of increased maturation possibly due to volcanic flows (Simoneit et al., 1981). The relative increase in Rock-Eval $T_{\max }$ and $(\mathrm{C} / \mathrm{N})_{\text {org }}$ ratios for three samples, noted in Table 6 indicate kerogen maturation by volcanic flows (Peters et al., 1983). Visual kerogen analysis identifies palynomorphs, possibly Paleocene in age, which appear too mature for the existing thermal gradient (Table 1). Thermal alteration index $\left(\mathrm{TAI}_{\mathrm{DRC}}\right)^{4}$ values of these particles are $4+$, which is equivalent to a vitrinite reflectance $\left(R_{0}\right)$ of $\approx 0.7 \%$. No less mature material was found and the reworked palynomorphs had TAI $\mathrm{TRC}_{\mathrm{DRC}}=6\left(R_{0} \approx 0.95 \%\right)$. Visual analysis of OM also shows abundant carbonized material, wood fragments, and grainy (perforated) amorphous matter, believed to be bacterially degraded. Spore, cuticle, and fungal particles are minor. The identified palynomorphs (Paleocene?) include: monosulcate pollen (palm), trilete spore (fern), and tricolporate grain (Castanea or Cyrilla).

The geochemical and visual data suggest that the extensive volcanic activity during Paleocene (Phase I) caused thermal maturation of OM. Pyrol/MS and visual kerogen for two samples $(555-87-5,145-147 \mathrm{~cm}$ and $555-92-2,148-150 \mathrm{~cm}$ ) show no immature kerogen. RockEval and $(\mathrm{C} / \mathrm{N})_{\text {org }}$ ratios indicate that thermal maturation is localized and probably due to lava flows and intrusions.

The saturate extract of Sample 555-92-2, 148-150 cm was analyzed by GC/MS for biomarkers (terpanes, $m / e$ 191; and steranes, $m / e$ 217) and saturates $(m / e ~ 57)$. The terpane biomarker scan is similar to that in Figure 7 but the epimers are at lower concentrations. These hopane

\footnotetext{
${ }^{4}$ Thermal alteration index (TAI ${ }_{\text {DRC }}$ ) used at Denver Research Center is a scale of 1-10 instead of the conventional TAI scale of 1-5 (Staplin, 1969).
}

stereoisomers are used to calculate the maturation ratios: $\mathrm{S} / \mathrm{S}+\mathrm{R}=59 \%$ and $\alpha, \beta / \beta, \beta=3.36$ (Table 5 ) suggesting mature $\mathrm{OM}$. The sterane steoisometers are undetectable in the saturate extract. The paraffin distribution (Fig. 8) shows a dominance of isoprenoids and isoparaffins suggesting "early" thermal generation of hydrocarbons (Peters et al., 1983).

Phase 2 of the isolation of Rockall is marked by cessation of extrusive activity, episodic shallowing and deepening of the basin, and periods of extensive sedimentation due to erosion of nearby, vegetated, volcanic highlands (site chapter, this volume). This phase extends through the early Eocene and is represented at Site 555 by Units IIIe-c and at Site 553 by Units IVf-c. At Site 555 sediments grade upward from volcanic tuffs with minor interlayers of terrestrial detritus (Unit IIIe) into carbonaceous mudstones and sandstones (Units IIId and IIIc) which are commonly carbonate cemented. Unit IIIc shows a transition to a heavy-mineral assemblage sourced by both S. Greenland and the Rockall Plateau.

Three samples from Site 555, Unit IIIe, exemplify the episodic changes in the source of OM (Fig. 6D), probably related to shallowing and deepening of the basin. Samples 555-67-3, 138-139 cm and 555-64-1, 102-103 contain carbonaceous layers $(1.10$ and $0.91 \%$ OC) of primarily continental material $\left(\mathrm{C} / \mathrm{N} \approx 34, \delta^{13} \mathrm{C}=\right.$ $-26.4 \%)$. Sample $555-64-3,117-118 \mathrm{~cm}(0.10 \% \mathrm{OC})$ lacks significant terrestrial input $\left(\mathrm{C} / \mathrm{N} \approx 12, \delta^{13} \mathrm{C}=\right.$ $-25.5 \%$ ) and is composed of highly oxidized marine $\mathrm{OM}$, with some reworked detritus. The pyrol/MS plot for Sample 555-64-1, 102-103 cm (Fig. 1D) shows a complex mixture containing different kerogen types of different maturations. This is indicated by the various hydrocarbon groups that are thermally released from the sample at increasing pyrolysis temperatures. The PHI (Table 4) is low (1.91), suggesting terrestrial, gas-prone OM. Visual kerogen assessment supports these evaluations (Table 1): Sample 555-64-1, 102-103 cm is "moderately-rich," containing dominant wood fragments and normal terrestrial debris. There is a rich spore assemblage of indigenous Eocene-Paleocene material including: Taxodium (cypress), Glyptostrobus (conifer), Pinus, Carya (hickory, etc.), Quercus (oak), and Castanea (horse- 


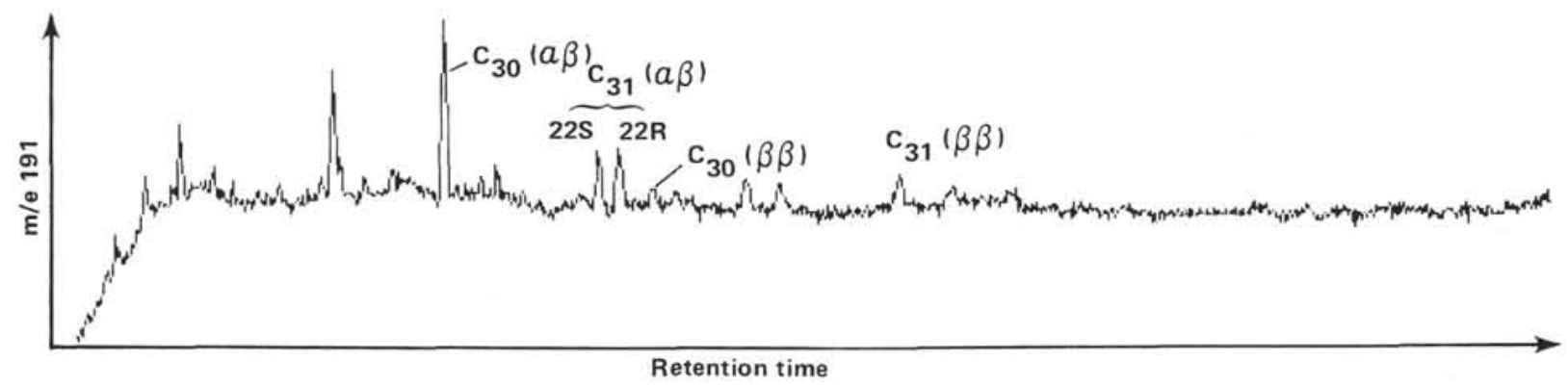

Figure 7. GC/MS scan of terpane "biomarkers" $(m / e$ 191) for Sample 553A-24-1, 23-24 cm, showing "mature" stereoisomer distribution. This low-OC $(0.37 \%)$ sample represents the "oxidized-marine phase" of deposition and the terpane "biomarkers" are probably due to reworked $O M$.

chestnut). The immaturity of these spores $\left(\mathrm{TAI}_{\mathrm{DRC}}=\right.$ $2^{-} \approx 0.4 \% R_{0}$ ) distinguishes this unit from the underlying unit (Unit IVb) containing lava flows and correlates with maturation indicated by pyrol/MS (Figs. $1 \mathrm{C}$ and 1D). Sample 555-64-1, 102-103 cm kerogen also includes minor grainy amorphous matter (bacterially degraded?), plant cuticle, reworked spore fragments and fungal hyphae. Sample 555-64-3, 117-119 cm is "very lean," containing minor terrestrial detritus, amorphous matter (fecal pellets), and trace spore fragments, suggesting a highly oxidized, marine environment and a minimum of terrestrial input. The GC/MS selective-ion scans $(\mathrm{m} / e$ $191,217)$ of the Sample 555-64-3, 117-119 cm extract showed no detectable sterane or triterpane biomarkers. This is not unreasonable considering the low OC content $(0.10 \%)$ of this sample and the small amounts of saturate biomarkers, previously discussed.

Phase 2 Paleocene deposition at Site 555 (Unit IIIe) consists primarily of volcanogenic sediments deposited in a shallow marine environment. Deposition fluctuates between periods dominated by low OC, highly oxidized marine OM and reworked detritus, and pulses of significant amounts of terrestrially derived OM. This pattern continues upward into Unit IIId (Fig. 6D) with sediments consisting primarily of carbonaceous mudstones and sandstones. The high OC layers are terrestrially derived, while the low OC layers show a more marine, highly oxidized OM.

The early Eocene sediments of Unit IIIc represent a shallow tidal basin (site chapter, this volume). The upward trend in this unit is toward increased volcanic sediments and a more marine OM. Unit IIIc contains the richest of all Rockall samples, averaging $1.6 \%$ OC (seven samples, with a range of $0.10-4.10 \%$ ). The carbonisotope data (Fig. 6D and Table 3) show a gradual trend $(-27.0$ to $-24.7 \% 0)$ toward a more marine influence at the upper part of the unit. Rapidly changing environmental conditions are indicated by large fluctuations in $(\mathrm{C} / \mathrm{N})_{\text {org }}$ and $(\mathrm{C} / \mathrm{P})_{\text {org }}$ data.

Sample $555-40-5,138-139 \mathrm{~cm}(0.94 \%$ OC) shows the least terrestrial character by Rock-Eval analysis (site chapter, this volume), being intermediate between type II and type III kerogen, and the greatest "hydrocarbon potential" (2.8 mg HC/g rock). Carbon isotope $(-26.4 \%)$ and $(\mathrm{C} / \mathrm{N})_{\text {org }}(37)$ suggest a terrestrial/marine mixture. Pyrol/MS yields a hydrocarbon pyrolyzate pattern simi- lar to that illustrated in Figure 1E. The PHI (2.49) also suggests a mixture of marine and terrestrial sources. The GC/MS terpane maturation ratios (Table 5) suggest that this sample is mature $(\mathrm{S} / \mathrm{S}+\mathrm{R}=51 \%, \alpha, \beta / \beta, \beta$ $=2.61$ ), but not as mature as the thermally stressed sample in Section 555-92-2. This "maturation" is probably due to reworked materials and the absence of saturate extractable biomarkers. Visual kerogen analysis shows that Sample $555-40-5,138-139 \mathrm{~cm}$ is dominated by porous, grainy, amorphous matter (bacterially degraded?), with wood and fusinite. Pyrobitumen, cuticle, and resin are present.

Sample $555-37-2,21-25 \mathrm{~cm}(4.1 \%$ OC) appears to be a "coal seam" deposited in a marine environment. Organic geochemical data (Table 3) suggest terrestrial OM. Rock-Eval characterizes this sample as type III, gasprone kerogen with multiple $S_{2}$ peaks. Visual kerogen analysis of this sample shows it is "very rich" and dominated by coarse wood and fusinite. Spores, pollen, cuticle, and fungal debris are common. Fecal pellets are minor but may suggest a marine environment of deposition. Samples 555-36, CC and 555-36-1, 11-12 are carbonate-cemented mudstones (78 and $45 \% \mathrm{CaCO}_{3}$ ) containing 0.10 and $0.71 \%$ OC, respectively. Several geochemical factors (Table 3 ) indicate the marine character of these samples, including carbon isotopes $(-25.0$ and $-24.7 \%$ ) and organic $P$ contents. The phosphorus is probably related to the carbonate cementation and/or the marine source of the carbonate discussed earlier. The pyrol/MS PHI (3.46-indicates a slightly more hydrocarbon-prone (marine) OM. Visual kerogen analysis of the sample in Section 555-36-1 notes grainy, amorphous matter (bacterially degraded?) and fecal pellets which suggest a marine environment. There is also the normal terrestrial/woody material and some spore, cuticle, and resin. Sample 555-34-4, 137-138 cm (1.95\% $\mathrm{OC})$ completes this unit with a return to primarily terrestrial OM: $\delta^{13} \mathrm{C}(-25.8 \%),(\mathrm{C} / \mathrm{P})_{\text {org }}=1477$, and minimal $\mathrm{CaCO}_{3}$ content. Pyrol/MS PHI (2.12) indicates a less oil-prone, more terrestrial $\mathrm{OM}$. The indigenous spore and pollen assemblage of this sample includes: Sequoia, Carpinus (hornbeam), Betula (birch) and cypress, and fern spores and palm pollen, possibly suggesting a warm climate.

Site 553 was located in the basinal west margin of the Edoras Bank, NW of Site 552 and toward the "outer- 


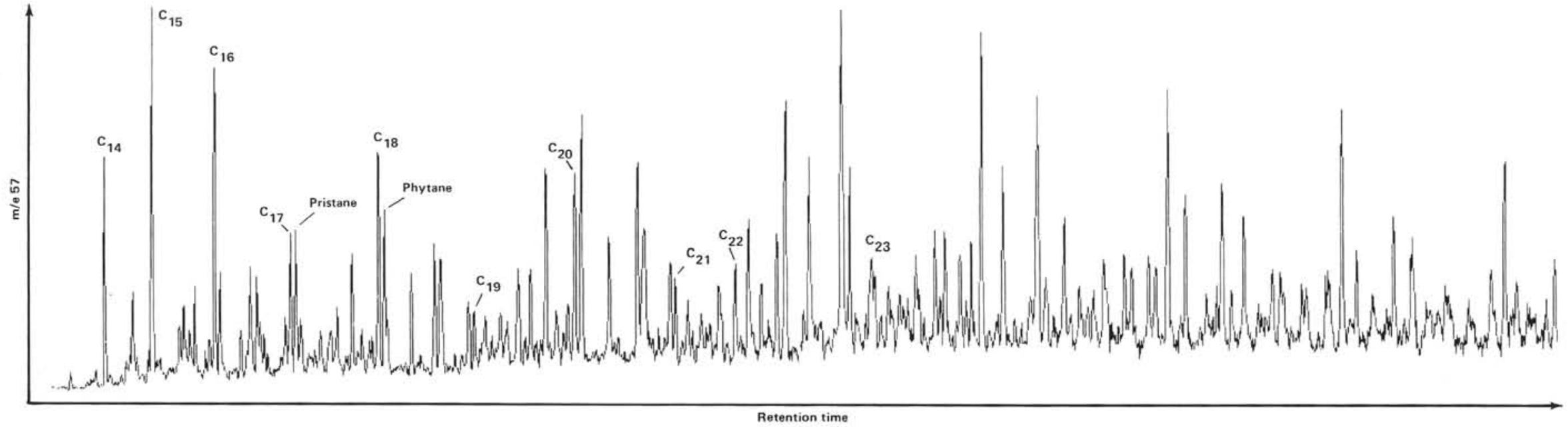

Figure 8. GC/MS scan of saturate hydrocarbons ( $m / e$ 57) for Sample 555-92-2, 148-150 cm, showing $n$-paraffins (identified) versus relatively large concentrations of isoprenoids and isoparaffins (largest peaks), which suggests "early" thermal generation (Peters et al., 1983). 
high" (Site 554) (site chapters, this volume). The sedimentary sequence at $553(\sim 501 \mathrm{~m})$ is intermediate in thickness between Site $555(\sim 672 \mathrm{~m})$ and Site 552 $(\sim 318 \mathrm{~m})$. Phase 2 at Site 553 (Units IVf-c) has a similar sediment lithology to Site 555 (Units IIIe-c). "Tuffaceous mudstones" with volcanic interbeds (Unit IVf), grade upward into sandstones (Unit IVd), and sandy mudstones (Unit IVc) with the appearance of detrital quartz and a change in the heavy-mineral suite. Disseminated carbonaceous material occurs throughout Unit IV, often in distinct laminae. As at Site 555, these laminae suggest large influxes of terrestrial detritus when OC is greater than $0.70 \%$. The low OC sediments contain marine highly oxidized, and reworked kerogen. In Table 3, Samples 553A-37-4, 123-125 cm, 553A-36-1, $114-116 \mathrm{~cm}, 553 \mathrm{~A}-22-5,104-105 \mathrm{~cm}$, and 553A-14-5, 106-107 $\mathrm{cm}$ show the terrestrial detrital phase, and Samples 553A-27-4, 125-127 cm, 553A-24-1, 23-24 cm, and 553A-21-1, 125-126 cm show the oxidized marine phase. The $(\mathrm{C} / \mathrm{N})_{\text {org }}$ ratios of the high $\mathrm{OC}$, terrestrial group average $\approx 31$ (29-32), while the low OC samples average $\approx 19(13-22)$. The $(\mathrm{C} / \mathrm{P})_{\text {org }}$ ratios and carbon isotopes appear to fluctuate in a similar manner (Fig. $6 \mathrm{~B})$. These results also enable us better to understand the Rock-Eval analyses (site chapter, this volume). The high OC terrestrial samples all plot near the type III kerogen line (OI average $78 \mathrm{mg} \mathrm{CO} / \mathrm{g} \mathrm{C}_{\text {org }}$ ). ${ }^{5}$ Highly oxidized samples with low OC have high OI values $(>500$ $\mathrm{mg} \mathrm{CO} 2 / \mathrm{g} \mathrm{C}_{\text {org }}$ ). This is common for DSDP samples and is sometimes attributed to inorganic carbonate decomposition. As was discussed earlier (glacial-interglacial study), we feel the large OI is a characteristic of highly oxidized, immature, and/or reworked OM. This conclusion is supported by these samples with high OIs and no inorganic carbonate.

The Paleocene Unit IVf at Site 553 is characterized by tuffaceous mudstones, disseminated OM, and shallow-water benthic fauna. The rich organic mudstones show fine laminations indicating a lack of bioturbation and anoxic sedimentary conditions (Demaison and Moore, 1980). The high-OC Samples 553A-37-4, 123-125 cm and 553A-36-1, 114-116 cm are primarily terrestrial in character, although Sample 553A-36-1, 114-116 cm shows indications of a significant marine influence.

Visual kerogen assessment shows that the sample in Section 553A-36-1 is rich in wood fragments, pyrobitumen, amorphous matter, fecal pellets, fungal remains, and multicellular spores. Cuticle and higher plant spores are highly fragmented. Sample 553A-37-4, 123-125 cm contains primarily the aforementioned terrestrial material with the addition of sparse resin chips. There is only a trace of amorphous matter and no fecal pellets. From indigenous spores, Cedrus (cedar), Pinus, and a monolete fern were recognized. Pyrol/MS yields a fairly high PHI (6.29) for Sample 553A-36-1, and all the samples from Phase 2 at Site 553 show higher PHIs (average = 6.15 ) than the equivalent sequence at Site 555 (average

\footnotetext{
${ }^{5}$ Several replicate Rock-Eval analyses of Core 553A-36-1, 114-116 cm did not substantiate the high $\mathrm{HI}(800)$ found by shipboard analysis (site chapter, this volume). The average values obtained are $S_{1}=0.30, S_{2}=1.09, S_{3}=0.84, S_{2} / S_{3}=1.29, \mathrm{HI}=98, \mathrm{OI}=76$.
}

PHI $=2.60$ ) indicating a more oil-prone (marine) source and/or better preservation of OM. The GC/MS hopane maturation ratios (Table 5 and Fig. 9) suggest more immature OM in Sample 553A-37-4, 123-125 cm and 553A-36-1, 11-12 cm, relative to all other samples. Sample 553A-36-1, 11-12 cm also gave a small amount of extractable steranes shown in Figure 10. Table 5 includes a sterane ratio adapted from Shi et al. (1982) used to estimate relative terrestrial/marine character of OM. Although this ratio should be used with caution, it does suggest a more oil-prone character (marine) for the $\mathrm{OM}$ Sample 553A-36-1, 11-12 cm. This is in agreement with the sedimentology (fine laminations indicating anoxic sediments), visual kerogen (abundance of fecal pellets and amorphous matter), and pyrol/MS data, suggesting relatively more oil-prone kerogen $(\mathrm{PHI}=6.28$ and $\mathrm{PS}_{2}=6.91$ ).

Units IVd and IVc are primarily sandstones and mudstones, with macrofauna indicative of a high-energy, shallow marine environment (site chapter, this volume). The pyrol/MS orthographic plot (Fig. 1E and Table 4) of Sample 553A-21-1, 125-126 cm shows the relatively large amount of paraffins $(Z=1)$ generated from immature marine OM compared to more napthenic hydrocarbons at higher pyrolysis temperatures. Figures $1 \mathrm{~F}-$ $1 \mathrm{H}$ show plots of highly oxidized, immature marine OM. The PHI for Sample 553A-21-1, 125-126 cm is 8.79 , significantly hydrocarbon rich for this sequence (Table 4). GC/MS hopane maturation ratios (Table 5) and the hopane biomarkers (Fig. 7) indicate mature OM for samples from Sections 553A-24-1 and 553A-21-1. This is probably due to the reworked material and the oxidized (nonextractable) character of the indigenous OM. Visual kerogen suggests the terrestrial nature of Samples 553A-14-5, 106-107 cm and 553A-22-5, 104-105 cm with dominant wood fragments and other common terrestrial detritus, and small clumps of perforated amorphous matter (bacterially degraded?). Both cores contain reworked spores and fungal remains (Cretaceous or older). Indigenous spores and pollen include previously seen hickory, oak, palm, and a triporate grain Engelhardtia. The low-OC samples in Sections 553A-27-4, 553A-24-1, 553A-21-1, and 553A-18-1 contain wood and charred debris, intermittent grainy amorphous clumps and strands (bacterially degraded?), and reworked fungal, cuticle, and spore fragments. Indigenous spores and pollen include: Keteleeria (fir), and cypress, horsechestnut, pine, and oak. Sample 553A-21-1, 125-126 cm is distinguished by resin nodules.

Phase 3 of the isolation of Rockall is marked by accelerating subsidence and changes in source and sites of deposition. Depths of deposition increased and near the end of this phase a decrease in volcanic sediments is balanced by an increase in chalks $\left(\mathrm{CaCO}_{3}\right)$ (site chapter, this volume). At Site 554 (the "outer high") Phase 3 is represented by Unit IV, which consists of approximately $8 \mathrm{~m}$ of Eocene calcareous tuff and marlstone. Site 554 is the oceanward boundary of the Edoras Basin and biostratigraphy suggests a deep-shelf setting. A different sediment source for Site 554 is indicated by the lack of heavy minerals and terrigenous detritus. The source dif- 


\section{A. J. KALTENBACK ET AL.}

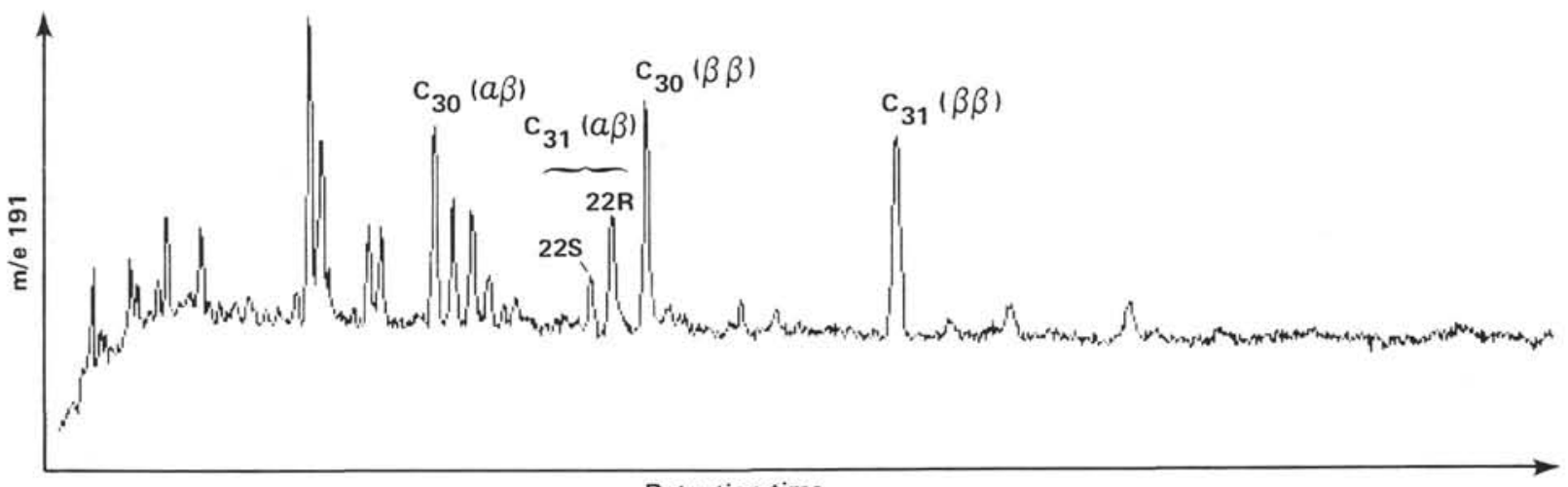

Retention time

Figure 9. GC/MS scan of terpane "biomarkers" ( $m / e$ 191) for Sample 553A-36-1, 114-116 cm, showing "immature" steroisomer distribution. This sample gave greatest amount of extractable biomarkers, possibly related to anoxic sedimentary conditions suggested by sedimentology (fine laminations).

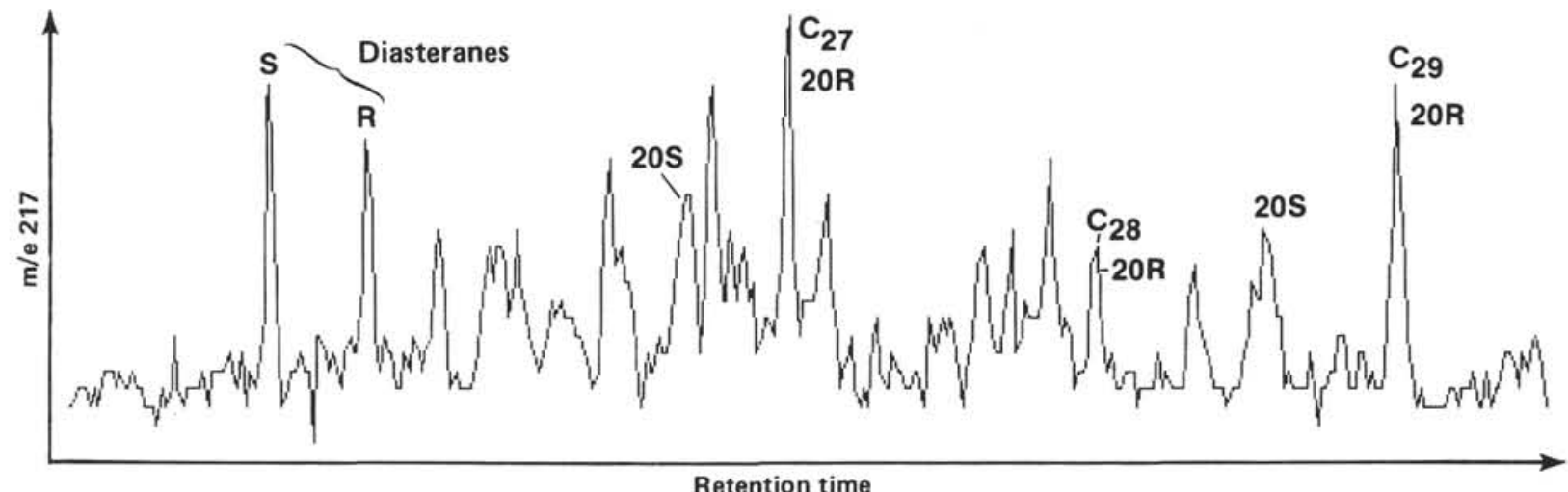

Figure 10. Sterane "biomarkers" ( $m / e$ 217) for Sample 553A-36-1, 114-116 cm (1.10\% OC), showing the highest concentrations of steranes of all samples analyzed by GC/MS (Table 5). The $\mathrm{C}_{29}(20 \mathrm{R}) / \mathrm{C}_{27}(20 \mathrm{R})$ ratio (adapted from Shi, et al., 1982) possibly indicates a significant marine contribution to this sample.

ference was also suggested by shipboard Rock-Eval analysis showing the absence of the "mature" reworked component seen at the other sites (site chapter, this volume). The $\mathrm{HI}\left(\approx 300 \mathrm{mg} \mathrm{HC} / \mathrm{g} \mathrm{C}_{\text {org }}\right.$ ) and very high OI ( $>1000 \mathrm{mg} \mathrm{CO} / \mathrm{g} \mathrm{C}_{\text {org }}$ ) are characteristic of highly oxidized, immature OM. This shorebased study differentiates the source of OM even more strikingly. The carbonisotope signature $(-25.1 \%)$ and organic $\mathrm{P}(\mathrm{C} / \mathrm{P}=15)$ suggest marine OM. A high inorganic $\mathrm{P}$ content (Sample 554-5-5, 13-15 cm) has been observed several times in this study for carbonate sediments, as has the relatively higher organic $\mathrm{P}$ content. The pyrol/MS plot (Fig. 1F) shows the distinct character of pyrolyzable hydrocarbons for Sample 554-5-5, 13-15 cm. This kerogen is immature and unique when compared to samples with a significant terrestrial component (Fig. 1D). Reworked material, usually seen in the $600-750^{\circ} \mathrm{C}$ range of the pyrogram, is absent from this sample. The PHI (Table 4) is exceptionally high (30.27), indicating a very significant hydrocarbon yield for the low-OC content of the sample. Very immature marine OM may give abnormally high hydrocarbon yields, even if highly oxidized, due to the ease of cracking lipid-rich material as described by Peters et al. (1981). Visual kerogen analysis rates Sam- ples 554-6-2, 120-122 cm and 554-5-5, 13-15 cm as "verylean," with a trace of fusinite, wood, and grainy amorphous matter (bacterially degraded?).

Phase 3 is characterized by a change of the major depocenter to the west from the Hatton Basin (Site 555) to the Edoras Basin (Sites 552 and 553). Site 552 may have been flooded for the first time by the Eocene North Atlantic during this phase (Units IVc-a). The relatively thick sedimentary sequence deposited at Site $552(122$ $\mathrm{m}$ ) during Phase 3 is compared to less than $70 \mathrm{~m}$ of sediment at the other sites (Fig. 6 and site chapters, this volume). This sequence grades upward from calcareous $\left(\approx 20 \% \mathrm{CaCO}_{3}\right.$ ), biosiliceous mudstones (Unit IVc), to volcanic sediments (Unit IVb), with decreased biogenic input ( $\approx 10 \% \mathrm{CaCO}_{3}$ ) to volcanic and biosiliceous mudstones with $\approx 22 \% \mathrm{CaCO}_{3}$ (Unit IVa). Detrital quartz, terrestrial heavy minerals, and clays are noticeably sparse throughout Unit IV (site chapter, this volume).

The geochemical data show a trend toward more marine OM (Table 3 and Fig. 6A). The carbon-isotope values change from -28.6 to $-25.5 \%$ up the sequence and the $(\mathrm{C} / \mathrm{N})_{\text {org }}$ ratios are characteristic of oxidized, marine $\mathrm{OM}$. The $(\mathrm{C} / \mathrm{P})_{\text {org }}$ ratios show a concurrent decrease up the section to marine values (with increasing 
inorganic $\mathrm{P}$, organic $\mathrm{P}$, and $\mathrm{CaCO}_{3}$ ). This trend corresponds with increasing shelf depth interpreted from marine faunal associations. Pyrol/MS plots (Figs. 1G and $1 \mathrm{H})$ show the distinct character of this OM compared to the complex mixtures of samples with significant terrestrial components. Notice the immature, unimodal pyrolysis peaks, yielding paraffinic and mononapthenic or olefinic ( $Z=1$ and -1$)$ hydrocarbons, suggesting lipid-rich OM. These samples are similar to the sample from Section 554-5-5 (Fig. 1F) in their lipid-rich (marine) OM. The decrease in the reworked, high-temperature hydrocarbon component from Samples 552-16-1, $10-14 \mathrm{~cm}$ to $552-9-4,112-114 \mathrm{~cm}$ (Figs. $1 \mathrm{G}$ and $1 \mathrm{H}$ ) indicates a decrease in the land-derived, reworked component of the OM. The PHIs for these samples are very high (26.59 and 135.2, respectively), again indicating the hydrocarbon-prone character of highly oxidized, marine OM. Visual kerogen shows Sample 552-21-2, 131-133 $\mathrm{cm}$ as "very-lean," containing a detrital background of fusinite, vitrinite, pyrobitumen, and some reworked acritarchs (cysts) and microforam linings (Cretaceous or older), as well as indigenous horsechestnut grains. The more marine Samples 552-9-4, 112-114 cm and 552A$38-2,47-48 \mathrm{~cm}$ show only residual carbon and grainy amorphous matter (bacterially degraded?).

At Site 553, NW of Site 552, Phase 3 is represented by Units IVa and IVb. These units are primarily chalks $\left(\approx 70 \% \mathrm{CaCO}_{3}\right)$ with a minor biosiliceous component and no detrital sedimentary matter. Marine fauna suggest outer shelf depths of deposition (site chapter, this volume). The OC content is very low $(0.01$ and $0.05 \%)$, yet the organic P in Sample 553-10-2, $25 \mathrm{~cm}$ is the highest value observed (Table 3), again suggesting the relationship between calcareous sediments and organic P. Visual kerogen of this sample identifies residual background and grainy amorphous matter (bacterially altered?), distinguishable from other sites only by smaller particle size.

There is a decrease in sedimentation during Phase 3 at Site 555 to the northeast, which was a major deposition site in earlier phases. The heavy mineral composition is derived solely from the Rockall (the S. Greenland influence is absent) (site chapter, this volume). Sample $555-31-1,138-139 \mathrm{~cm}$ shows the last vestiges of terrestrially sourced $\mathrm{OM}$ before this site subsided to Miocene depths. Sample 553-31-1, 138-139 cm, with moderate OC content $(0.25 \%)$, shows the characteristic terrestrial/marine kerogen mix by geochemical parameters (Table 3 and Fig. 6D).

Phase 4 includes erosional and depositional sequences before Rockall subsides to Miocene and present-day depth. This is suggested by the noncontinuous sedimentation, missing sedimentary sections, and periods of minimal deposition (site chapter, this volume). At Site 554 , Oligocene Sample 554-5-2, 5-7 cm, was deposited at greater than $700 \mathrm{~m}$ water depth during the final phase of isolation of Rockall. This sample is similar to the highly oxidized, deep marine Miocene and interglacial (Pleistocene) sediments.

\section{CONCLUSIONS}

This study of the sedimentary OM of Leg 81 (Rockall Banks) describes the types of OM preserved in various paleoenvironments, the significance and limitations of various geochemical parameters, and the changes in $\mathrm{OM}$ related to the isolation of Rockall from Greenland.

The Pleistocene samples show differences in OM for the glacial and interglacial phases. Most $\mathrm{OM}$ in both the glacial and interglacial sediments is highly oxidized, resistant, and nonpyrolyzable RC (at Rock-Eval pyrolysis conditions). This OM is probably the reworked, detrital component identified by visual kerogen analyses. Glacial sediments contain more OC (average $=0.17 \%$ ), with a larger proportion of $\mathrm{RC}$, probably reflecting increased erosion of continental and shelf areas during low sea-level. Interglacial sediments contain relatively high organic $\mathrm{P}$ levels (with maximum $\mathrm{CaCO}_{3}$, minimum $\mathrm{RC}$ ), whereas organic $\mathrm{P}$ decreases to nondetectable for glacial sediments (minimum $\mathrm{CaCO}_{3}$, maximum RC). The sum of geochemical information suggests that interglacial periods are dominated by deposition of highly oxidized, marine OM related to the skeletal organic matrix of calcareous organisms. In addition, Rock-Eval data indicate no significant inorganic-carbonate contribution to the $S_{3}$ peak of these high-carbonate $(80 \%)$, low-organic-carbon $(<0.1 \%)$ samples.

The Pliocene-Miocene sediments, primarily pelagic biogenic carbonates, such as the Pleistocene interglacial sediments, consist of a mixture of highly oxidized, marine $\mathrm{OM}$ and reworked/resistant, terrestrial detritus.

Paleocene-Oligocene OM was studied in the context of the geologic history of the isolation of Rockall from Greenland (Phase 1-4). Igneous Phase 1, characterized by lavas, showed apparent in situ thermal maturation of $\mathrm{OM}$ in interbedded sediments and primarily terrestrial OM. Phase 2, marked by the cessation of extrusive activity and episodic changes in depth of deposition, contains $\mathrm{OM}$ reflecting these cycles. The high-OC terrestrial sediments probably indicate shallow deposition, whereas the low-OC highly oxidized, marine sediments probably indicate greater depths of deposition. Site 555 shows a major terrestrial input and Site 553 has a slightly more marine character during Phase 2 . At both sites, the early Eocene sediments deposited at the end of Phase 2 are richer in $\mathrm{OM}$ and this OM suggests a more marine environment. This trend is probably related to the transition in heavy minerals to an assemblage sourced by both $\mathrm{S}$. Greenland and Rockall. Visual kerogen indicates that indigenous vegetation included mountain and warm/temperate climate species. Phase 3 is marked by accelerating subsidence of western Rockall (Edoras Bank, Sites 552, 553, and 554) and increased deposition at these sites relative to Site 555 (Hatton-Edoras Basin). The increasingly marine character of the $\mathrm{OM}$ at these sites is due to increasing depth of deposition and the disappearance of terrestrial sources in the area. The lack of a terrestrial source is due to subsidence of Rockall and the increase in distance of S. Greenland. Phase 4 samples contain 
marine, oxidized OM, similar to that of Pleistocene-Miocene sediments.

The overall petroleum potential of sediments containing more than $0.5 \% \mathrm{OC}$ is poor because of their highly oxidized nature and dominantly terrestrial OM. These sediments are also immature with the exception of those heated by volcanic flows.

\section{ACKNOWLEDGMENTS}

We wish to express our thanks to DSDP/IPOD and Marathon Oil Company for allowing us to conduct this study; R. Chormann and P. Donahue (phosphorus analysis), G. Gamby, H. Heck (visual kerogen), L. B. T. Smith (Carbon, GC/MS), K. Lintelmann (LC), and D. Wallwey (isotopic analysis) for their analytical assistance; and J. Melton, B. Daly, J. Parker, D. Hite, and R. Bos for technical assistance. Special thanks to H. Maxwell for pyrol/MS assistance, and B. Benzel, J. May, K. Peters, and G. Claypool for reviews and suggestions.

\section{REFERENCES}

Aspila, K., Agemian, H., and Chan, A., 1976. A semi-automated method for the determination of inorganic, organic and total phosphate in sediments. Analyst, 101:187-197.

Bornemisza, E., and Igue, K., 1967. Comparison of three methods for determining organic phosphorous in Costa Rican soils. Soil Sci., 103:347-353.

Bray, J., 1973. The behavior of phosphate in the interstitial waters of Chesapeake Bay sediments [Ph.D. dissert.]. The Johns Hopkins Univ., Baltimore, p. 149.

Carter, P., 1978. Adsorption of amino-acid-containing organic matter by calcite and quartz. Geochim. Cosmochim. Acta, 42:1239-1242.

Carter, P., and Mitterer, R., 1978. Amino acid composition of organic matter associated with carbonate and non-carbonate sediments. Geochim. Cosmochim. Acta, 42:1231-1238.

Chung, H., and Sackett, W., 1979. Use of stable carbon isotope compositions of pyrolytically derived methane as maturity indices for carbonaceous materials. Geochim. Cosmochim. Acta, 43:1979-1988.

Clementz, D., 1979. Effect of oil and bitumen saturation on sourcerock pyrolysis. Am. Assoc. Pet. Geol. Bull., 63:2227-2232.

Clementz, D., Demaison, G., and Daly, A., 1979. Wellsite geochemistry by programmed pyrolysis. Proc. Annu. Offshore Technol. Conf., 11th, Houston, April 30-May 3, pp. 465-470.

Demaison, G. J., and Moore, G. T., 1980. Anoxic environments and oil source bed genesis. Am. Assoc. Pet. Geol. Bull., 64:1179-1209.

Erdman, J., and Schorno, K., 1979. Geochemistry of carbon: Deep Sea Drilling Project Leg 43. In Tucholke, B. E., Vogt, P. R., et al., Init. Repts. DSDP, 43: Washington (U.S. Govt. Printing Office), 651-656.

1980. Geochemistry of carbon: Deep Sea Drilling Project Sites 415 and 416. In Lancelot, Y., Winterer, E. L., et al., Init. Repts. DSDP, 50: Washington (U.S. Govt. Printing Office), 625-627.

Espitalié, J., Madec, M., and Tissot, B., 1977. Source rock characterization method for petroleum exploration. Proc. Ann. Offshore Technol. Conf., 9th, Houston, May 2-5, pp. 439-448.

Froelich, P., Bender, M., Luedtke, N., Heath, G., and DeVries, T., 1982. The marine phosphorous cycle. Am. J. Sci., 282:474-511.

Galimov, E., Kodina, L., Shirinsky, V., Drozdova, T., Generalova, V., Bogachova, M., Chinyonov, V., and Bannikova, L., 1980. A study of organic matter from deep oceanic bore holes, Deep Sea Drilling Project Sites 415 and 416, in the Moroccan Basin. In Lancelot, Y., Winterer, E. L., et al., Init. Repts. DSDP, 50: Washington (U.S. Govt. Printing Office), 575-600.

Gjessing, E., 1976. Physical and Chemical Characteristics of Aquatic Humus: Ann Arbor (Ann Arbor Science).

Lyons, W., and Gaudette, H., 1979. Sulfate reduction and the nature of organic matter in estuarine sediments. Org. Geochem., 1: 151-155.

MacKenzie, A., Brassell, S., Eglinton, G., and Maxwell, J., 1982. Chemical fossils: the geological fate of steroids. Science, 217: 491-504.

MacKenzie, A., Patience, R., and Maxwell, J., 1980. Molecular parameters of maturation in the toarcian Shales, Paris Basin,
France-I. Changes in the configurations of acyclic isoprenoid alkanes, steranes and triterpanes. Geochim. Cosmochim. Acta, 44: 1709-1721.

Morse, J., and Cook, N., 1978. The distribution and form of phosphorous in North Atlantic Ocean deep-sea and continental slope sediments. Limnol. Oceanogr., 23:825-830.

Murphy, J., and Riley, J. P., 1962. A modified single solution method for the determination of phosphate in natural waters. Anal. Chim. Acta, 27:31-36.

Nissenbaum, A., 1979. Phosphorous in marine and non-marine humic substances. Geochim. Cosmochim. Acta, 43:1973-1978.

Patton, J., Choquette, P., Guennel, G., and Kaltenback, A., in press. Organic geochemistry and source-rock characteristics of Late to Mid-Cretaceous deep-sea carbonates Sites 535 \& 540, Leg 77. In Buffler, R. P., Schlager, W., et al., Init. Repts. DSDP, 77: Washington (U.S. Govt. Printing Office).

Patton, J., and Moore, A., 1982. Thermolysis/mass spectrometry of kerogen. Int. Symp. Anal. Pyrolysis, Proc., Sth, Vail, Colo., Sept. 26-30. (Abstract)

Pedersen, T., 1983. Increased productivity in the eastern equatorial Pacific during the last glacial maximum (19,000 to 14,000 yr B.P.). Geology, 11:16-19.

Peters, K., Rohrback, B., and Kaplan, I., 1981. Geochemistry of artificially-heated humic and sapropelic sediments-I: Proto-kerogen. Am. Assoc. Pet. Geol. Bull., 65:688-705.

Peters, K., and Simoneit, B., 1982. Rock-eval pyrolysis of Quaternary sediments from Leg 64, Sites 479 and 480 , Gulf of Calif. In Curray, J. R., Moore, D. G., et al., Init. Repts. DSDP, 64: Washington (U.S. Govt. Printing Office), 925-931.

Peters, K., Whelan, J., Hunt, Jr., and Tarafa, M., 1983. Programmed pyrolysis of organic matter from thermally altered Cretaceous black shales. Am. Assoc. Pet. Geol. Bull., 67:2137-2146.

Rashid, M., and Reinson, G., 1979. Organic matter in surficial sediments of the Miramichi Estuary, New Brunswick, Canada. Estuarine Coastal Mar. Sci., 8:23-36.

Redfield, A., Ketchum, B., and Richards, F., 1963. The influence of organisms on the composition of seawater. In Hill, M. (Ed.), The Sea (Vol. 2): New York (Interscience), 26-77.

Roberts, A., Palacas, J., and Frost, I., 1973. Determination or organic carbon in modern carbonate sediments. J. Sediment. Petrol., 43: $1157-1159$.

Robinson, C., 1971. Low-resolution mass spectrometric determination of aromatics and saturates in petroleum fractions. Anal. Chem., 43:1425-1434.

Sandstrom, M., 1982. Diagenesis of organic phosphorous in marine sediments: Implications for the global carbon and phosphorous cycles. In Freney, J., and Galbally, I. (Eds.), Cycling of Carbon, Nitrogen, Sulfur, and Phosphorous in Terrestrial and Aquatic Ecosystems: Berlin (Springer-Verlag), 133-141.

Saunders, W., and Williams, E., 1955. Observations on the determination of total organic phosphorous in soils. J. Soil Sci., 6: 254-267.

Seifert, W., and Moldowan, J., 1980. The effect of thermal stress on source rock quality as measured by hopane sterochemistry. In Douglas, A., Maxwell, J. (Eds.) Advances in Organic Geochemistry 1989: Oxford (Pergamon), 229-237.

Shi, J. Y., MacKenzie, A., Alexander, R., Eglinton, G., Gowar, A., Wolf, G., and Maxwell, J., 1982. A biological marker investigation of petroleums and shales from the Shengli Oilfield, the People's Republic of China. Chem. Geol., 35:1-31.

Simoneit, B., 1980. Organic geochemistry of Mesozoic sediments from DSDP Site 330, Falkland Plateau. In Lancelot, Y., Winterer, E. L., et al., Init. Repts. DSDP, 50: Washington (U.S. Govt. Printing Office), 637-641.

Simoneit, B., Brenner, S., Peters, K., and Kaplan, L., 1981. Thermal alteration of Cretaceous black shale by diabase intrusions in the Eastern Atlantic-II. Effects on bitumen and kerogen. Geochim. Cosmochim. Acta, 43:111-126.

Sommers, L., Harris, R., Williams, J., Armstrong, D., and Syers, J., 1970. Determination of total organic phosphorous in lake sediments. Limnol. Oceanogr., 15:301-304.

Souron, C., Boulet, R., and Espitalié, J., 1974. Etude par spectrometric de masse de la décomposition thermique sous vide de kerogenes appartenant à deux lignées evolutives distinctes. Rev. Inst. Fr. Pet., 29:661-678. 
Staplin, F., 1969. Sedimentary organic matter, organic metamorphism, and oil and gas occurrence. Bull. Can. Pet. Geol., 17: 47 66.

Tissot, B., Demaison, G., Masson, P., Delteil, J. R., and Combaz, A., 1980. Paleoenvironment and petroleum potential of Middle Cretaceous black shales in Atlantic basins. Am. Assoc. Pet. Geol. Bull. 64:2051-2063.

Waples, D., 1977. C/N ratios in source rock studies. Colo. Sch. Mines Miner. Ind. Bull., 20:1-7.
Waples, D., and Sloan, J., 1980. Carbon and nitrogen profiles in deep-sea sediments: new evidence for bacterial diagenesis at great depths of burial. In Klein, G. de V., Kobayashi, K., et al., Init. Repts. DSDP, 58: Washington (U.S. Govt. Printing Office), 745-754.

Williams, J., Syere, J., Walker, T., and Rex, R., 1970. A comparison of methods for the determination of soil organic phosphorus. Soil Sci., 110:13-18.

Date of Acceptance: December 1, 1983 